\title{
Meanings and Functions of the Royal Portraits of the Navarrese Dynasty in the Kingdom of León, 1038-1109
}

\author{
Gerardo Boto Varela
}

The Kingdom of León came into being when the Asturian dynasty selected the city of León, originally a Roman military encampment, as its new political capital and the site of the coronation of the reges Legionis. The borders of the kingdom changed over the centuries, due to conflicts with the Umayyad Caliphate (929-1031), the Taifa dominions (1031-1092), the Almoravid Empire (1062-1147), the Almohad Empire (1147-1269), and the Christian kingdoms of Castile and Portugal. The regnum Legionense existed as a self-sufficient sovereign entity from 910 to $1230 .{ }^{1}$ García I (r. 910-914), Ordoño II (r. 914-924), and Fruela II (r. 924-925) were the first three monarchs to rule from the civitas of León and were the sons of Alfonso III (r. 866-910), the last sovereign to locate the seat of his power in Oviedo. This continuity meant that Asturian regal authority continued in León throughout the 1oth century and into the first third of the nth century. The rulers of the walled city claimed a connection with the long extinct and yearned-for kingdom of the Visigoths. ${ }^{2}$ Dynastic change came, however, after the rule of Bermudo III (r. 1028-1037), who perished in the Battle of Tamarón at the hands of his brother-in-law Fernando de Navarra (r. 1038-1065). After this struggle, the wife of Fernando and sister of Bermudo III, Sancha Alfónsez (1037-1067), became queen and the de facto last representative of the Asturian-Leonese line. Her children - Urraca of Zamora, Sancho II of Castile (r. 1065-1072), Elvira of Toro, Alfonso VI of León (r. 10651109), and García II of Galicia (r. 1066-1072) - as descendants of Fernando I,

1 In 1296, there was a brief attempt at political rehabilitation. Gerardo Boto Varela, "Sobre reyes y tumbas en la catedral de León. Discursos visuales de poder político y honra sacra," in $L a$ Catedral de León en la Edad Media, eds. Joaquín Yarza, María V. Herráez, and Gerardo Boto (León, 2004), pp. 305-65, esp. 306.

2 Gaël Le Morvan, "Reinos e imperio: la Historia legionensis (llamada silensis) y la reivindicación leonesa de la herencia visigótica," e-Spania 14 (2012). Accessed 2019 Oct 1; Georges Martin, "La Historia legionensis (llamada silensis) como memoria identitaria de un reino y como autobiografía," e-Spania 14 (2012). Accessed 2019 Aug 11.

(C) GERARDO BOTO VARELA, 2022 | DOI:10.1163/9789004511583_013

This is an open access chapter distributed under the terms of the CC BY-NC 4.0-licensesoto Vare la - 9789004511583 
were sovereigns of the Navarrese dynasty $(1038-1126) .{ }^{3}$ This line lasted until the death of Urraca (r. 1109-1126), who - with her husband, the princeps Raimundo of Burgundy (1070-1107) - produced a son and successor, Alfonso VII (r. 11261157), the first Leonese king of the Burgundian dynasty.

The present study analyses the images of royal sovereignty produced under the patronage and protection of the Leonese king and founder of the Navarrese dynasty, Fernando I, and his family, namely his wife Sancha, his firstborn daughter, the infanta Urraca, and his second-born son, King Alfonso VI. The images are found in private manuscripts, in rarely seen reliquaries, in murals for private funerary spaces, as well as in coinage and monumental sculpture, which were potentially on view to all members of society. ${ }^{4} \mathrm{~A}$ lack of space prevents me from analysing the royal images produced during the rule of the final representative of the dynasty, Queen Urraca, the firstborn daughter of Alfonso VI and the first queen to govern in her own right in medieval Hispania. ${ }^{5}$

The choice of this subject matter also gestures beyond the Navarrese dynasty itself in contextualizing the radical change that began with Fernando I with regard to the relationship between monarchs and their images. The surviving artefacts show that there was no figurative royal iconography in the Kingdoms of Asturias ${ }^{6}$ and León prior to the arrival of the Navarrese and their visual culture. However, it is well known that from the 1oth century in the Kingdom of Pamplona, representations of monarchs reflected both the present and the Visigothic past. It can be inferred that the iconographic proliferation of the royal countenance in León during the mid-1th century was a response to the figurative culture in which Fernando I had been steeped since his infancy and of which he wanted to make judicious use. Royal images were a practical

3 José María Mínguez Fernández, "Contexto social y político-militar del Reino de León al advenimiento de la dinastía navarra," in Alfonso VI y su época. I. Los precedentes del reinado (966-1065), eds. Etelvina Fernández González, and Javier Pérez Gil (León, 2007), pp. 17-35.

4 To put the discussion in its context, see: John W. Williams, "Fernando I and Alfonso VI as Patrons of the Arts," Anales de historia del arte 2: Alfonso VI y el arte de su época, eds. Javier Martínez de Aguirre, and Marta Poza (Madrid, 2011), 413-35. Although it does not deal with the Kingdom of León, a systematic and exemplary study of medieval royal effigies can be found in: Marta Serrano Coll, Effigies Regis Aragonum. La imagen figurativa del rey de Aragón en la Edad Media (Zaragoza, 2015).

5 Therese Martin, Queen as King. Politics and Architectural Propaganda in Twelfth-century Spain (Leiden, 2006); Therese Martin, "De 'gran prudencia, graciosa habla y elocuencia' a 'mujer de poco juicio y ruin opinión': Recuperando la historia perdida de la reina Urraca," Compostellanum 5o/1-4 (2005), 551-78.

6 There is no firm basis for believing that the relief on the entrance to San Miguel de Lillo was intended to display a representation of the king, although it does refer to political authority through a figure depicted on a seat of honour. 
resource for this monarch, who implemented diligent administrative, ecclesiastic, fiscal, and artistic policies. He was a ruler who, above all, sought to make his kingdom predominant in the face of his native Navarre. Through the sword (the 1037 Battle of Tamarón and the 1054 Battle of Atapuerca), ${ }^{7}$ through ecclesiastic decrees (Council of Coyanza, 1055), ${ }^{8}$ and through art, Fernando I and Sancha managed to preserve Castile for León and, because of that, become the most powerful of the Iberian Christian sovereigns.

\section{The First Manifestation of the King: Authority towards the World and Penitence towards God}

Apart from the coins of a few Visigothic kings (Egica and Witiza, among others), we have no surviving images of the kings of the High Middle Ages prior to the illuminated figurative poem in the Codex Vigilanus (976). On one folio, in a reticular composition, appear the three Visigothic kings who promulgated the Visigothic Code (Chindasuinth, Recceswinth, and Egica), the two current kings of Pamplona and Viguera (Sancho Garcés II and Ramiro III), and a queen (Urraca Fernández). ${ }^{9}$ In addition and exceptionally, the miniaturist and scribe Vigila included a self-portrait with his socius (Sarracino) and his discipulus (García). ${ }^{10}$ The image was copied two decades later in the Codex Emilianense,

7 Alfonso Sánchez Candeira, Castilla y León en el siglo XI, estudio del reinado de Fernando I, ed. Rosa Montero Tejada (Madrid, 1999). pp. 150-53.

8 Sánchez Candeira, Castilla y León, p. 127.

$9 \quad$ José María de Eguren, Memoria descriptiva de los códices notables conservados en los archivos eclesiásticos de España (Madrid, 1859), p. 72; Francisco Javier Sánchez Cantón, Los retratos de los reyes de España (Madrid, 1948), p. 25; Manuel C. Díaz y Díaz, "Vigilán y Sarracino: sobre composiciones figurativas en la Rioja del siglo X," in Lateinische Dichtungen des X. und XI. Jahrhunderts: Festgabe für Walther Bulst zum 8o. Geburtstag, eds. Walter Berschin, and Reinhard Düchting (Heidelberg, 1981), pp. 6o-92; Soledad de Silva y Verástegui, "Los primeros retratos reales en la miniatura hispánica altomedieval. Los monarcas de Pamplona y de Viguera," Príncipe de Viana 16o-161 (1980), 257-61; Soledad de Silva y Verástegui, Iconografía del siglo X en el Reino de Pamplona-Nájera (Pamplona, 1984), pp. 418-21; Soledad de Silva y Verástegui, "La miniatura en el Reino de Pamplona-Nájera (905-1076)," in García Sánchez III 'el de Nájera' un rey y un reino en la Europa del siglo XI, ed. José Ignacio de la Iglesia Duarte (Nájera, 2005), pp. 327-65, esp. 339-41.

10 "Vigila scriba cum sodale sarracino presbitero pariterque cum garcea discipulo suo edidit hunc librum: mementote memorie eorum semper in benedictione." Codex Vigilanus, El Escorial, Real Biblioteca del monasterio, Ms d.1.2, fol. 428r. Year 976. Each of the nine representations of individuals, in their respective rectangles, is accompanied by circles at the corners, which evoke the nails that fixed the ivory plaques onto a wooden support. The general composition and the tonality of the miniature seem to replicate sumptuous works made of painted ivory. 
which reproduced the images of the six monarchs, with the same gestures and attributes, although the material and intellectual authors of this second manuscript, Belasco the scriba, Bishop Sisebuto, and the notary Sisebuto, were represented below. ${ }^{11}$

In Vigila's miniature, Sancho II (r. 943-994) is shown haloed, wearing an ankle-length tunic, cloak, and cape, with his left hand extended and his right hand holding the staff of office. His wife, Urraca, wears a tunic, cloak, cape, and headdress, with a flabelum in her left hand and the index finger of her right hand extended. Although these royal effigies differ from Carolingian representations insofar as they do not proclaim the Navarrese monarchs to be under divine patronage, they are still indebted to the representations elaborated in the scriptorium at Tours, as indicated by De Silva y Verástegui. ${ }^{12}$

Eight decades later, in 1055, the same year in which the Council of Coyanza reconfirmed the application of the Isidorian Rule to the monastic communities, the scribe Pedro and the miniaturist Fructuosus composed the Diurnal (book of daily hours) of Fernando I and Sancha, which is held in the church of San Martín Pinario in Santiago de Compostela (Figure. 11.1). ${ }^{13}$ From what we

11 Códice Emilianense, El Escorial, Real Biblioteca del monasterio, Ms d.1.1, fol. 453r. Year 992.

12 De Silva y Verástegui, Iconografía del siglo X, p. 420.

13 Libro de Horas diurnas (book of daily hours; known as the Diurnal of Fernando I and Sancha), 1055. Santiago de Compostela. Biblioteca de la Universidad, Ms 6og, Res. 1, fol. 6v: image of Fernando I and Sancha with a beardless man (the copyist Pedro? David the psalmist? Their son Sancho or Alfonso?). Marius Férotin, "Deux manuscrits wisigothiques de la Bibliothèque de Ferdinand Ier," Bibliothèque de l'École des Chartes 62 (1901), 374-87; Angel Sicart, Pintura medieval: la miniatura (Santiago de Compostela, 1981), pp. 22-44; Manuel C. Díaz y Díaz, Códices visigóticos en la monarquía leonesa (León, 1983), pp. 28991; Serafín Moralejo Álvarez, "Notas a la ilustración del Libro de Horas de Fernando I," in Libro de Horas de Fernando I de León. Edición facsímile do manuscrito 609 (Res. 1) da Biblioteca Universitaria de Santiago de Compostela, ed. Manuel C. Díaz y Díaz (Santiago de Compostela, 1995), pp. 53-63; John W. Williams, "León: The Iconography of a Capital," in Cultures of Power. Lordship, Status, and Process in Twelfth-Century Europe, ed. Thomas N. Bisson (Philadelphia, 1995), pp. 231-258, esp. p. 240; Manuel Castiñeiras, "Algunos usos y funciones de la imagen en la miniatura hispánica del siglo XI: los Libros de Horas de Fernando I y Sancha," in Congresso Peninsular de História da Arte. Propaganda \& Poder (Lisboa, 200o), pp. 74-94; Manuel Castiñeiras, "Libro de Horas de Fernando I y Sancha," in Maravillas de la España Medieval. Tesoro sagrado y monarquía, ed. Isidro Bango (Madrid, 20o1), pp. 232-34; Manuel Castiñeiras, "Libro de Horas," in Enciclopedia del Románico en Galicia 2, eds. José María Pérez González, and José Carlos Valle Pérez (Aguilar de Campoo, 2013), pp. 1143-49; Emmanuelle Klinka, "Ego misera et peccatrix ...: El Liber mozarabicus canticorum et horarum (Salamanca, MS 2668)," e-Spania 13 (2012). Accessed 2019 June 6; Soledad de Silva y Verástegui, "Imágenes matrimoniales en la Alta Edad Media en España: la pareja real," Príncipe de Viana 77/265 (2016), 581-610; Jesús Rodríguez Viejo, "Imagen y devoción en el Diurnal de Fernando y Sancha," Románico 26 (2018), 8-15; 
know according to surviving works, this codex contains the first representation of a Leonese sovereign. In a purple-blue frame, Fernando I and Sancha flank an individual (whose identification is controversial) who is holding a golden object, perhaps the very same text, and who is dressed in a silk skirt and tunic. The face of this male figure is turned towards the queen as if seeking her acquiescence, as suggested by John W. Williams and Serafín Moralejo Álvarez. ${ }^{14}$ The figures appear below a splendid palatial drape ${ }^{15}$ which speaks to the true royal majesty of the personages. ${ }^{16}$ Less abstract is the faithful portrayal of king: he is shown crowned and without a halo, standing upright, holding a royal staff with a lion's head on the tip, and wearing a purple-blue, ankle-length tunic or tegmen, a purple-red pallium over his left shoulder, and high, red-laced boots, ${ }^{17}$ in imitation of the footwear worn by Byzantine emperors and popes. As has been asserted elsewhere, here the image of Fernando I depicts the monarch, who was endorsed by his tragic victory over his brother at Atapuerca (1 September 1054), as a modern David, ${ }^{18}$ the very paradigm of a king chosen by God.

It is clear that, if the artistic language of the miniature is indicative of the vanguard of the Romanesque, the iconographic model is undeniably high medieval. Thus, with the exception of the halo, the depiction of the Leonese

Kristin Böse, Von der Rändern Gedacht. Visuelle Rahmungsstrategien in Handschriften der Iberischen Halbinsel (Cologne, 2019), pp. 263-64.

14 Joaquin Yarza Luaces, Historia del Arte Hispánico 2, La Edad Media (Madrid, 1980), p. 104 (suggests that it represents David with the psalms); John W. Williams, "Prayer Book of Ferdinand and Sancha," in The Art of Medieval Spain, a.d. 500-1200 (New York, 1993), p. 29o; Moralejo Álvarez, "Notas a la ilustración," p. 54 (identifies it as the scribe Petrus); Francisco Prado-Vilar, "Lacrimae rerum: San Isidoro de León y la memoria del padre," Goya 328 (2009), 195-221 (interprets the figure as his son, the future king Alfonso VI); Williams, "Fernando I and Alfonso VI," pp. 417-19 (identifies it as the miniaturist Fructuosus); De Silva y Verástegui, “Imágenes matrimoniales," p. 598 (identifies it as Petrus).

15 This is the first Hispanic example of a 'court portrait,' see: Moralejo Álvarez, "Notas a la ilustración," p. 54.

16 Johann Konrad Eberlein, Apparitio regis - revelatio veritatis: Studien zur Darstellung des Vorhangs in der bildenden Kunst von der Spätantike bis zum Ende des Mittelalters (Wiesbaden, 1982), pp. 108-22.

17 The historiographical debate regarding the issue of colour is described in: Ana Villanueva Fernández, "La indumentaria regia en el Reino de León en el siglo XI: el libro de horas de Fernando I y Doña Sancha," in Imágenes del poder en la Edad Media. Estudios 'in memoriam' del Prof. Dr. Fernando Galván Freile 2 (León, 2011), pp. 485-5oo, esp. 49o.

18 Moralejo Álvarez, "Notas a la ilustración," p. 62; Klinka, "Ego misera et peccatrix ...," n. 4749. The iconographic analogies between the figures of Fernando I (fol. 6v) and King David (fol. 29v) are discussed in: Villanueva Fernández, "La indumentaria regia en el Reino de León," pp. 496-97. The idea of the sovereign as the new David spread throughout Latin Europe based on Byzantine models: Ildar H. Garipzanov, The Symbolic Language of Authority in the Carolingian World (c. 751-877) (Leiden, 2008), pp. 225-27. 
king is a stylistically modern attempt to imitate the codified image of his forbearer Sancho Garcés II. ${ }^{19}$ Moreover, in contrast to the finger-pointing gesture that Vigila assigned to Urraca, the image of Sancha in the book of hours shows her presenting the book with hands outstretched, just like Sancho II in the Codex Vigilanus. It is obvious that, faced with the lack of a vernacular tradition reflected in either coins or stamps, the Leonese miniaturist resorted to the visual types that had emerged in Navarrese art of the 1oth century.

The debt becomes even more apparent when one compares the representation of the royal Leonese couple in the book of hours with that of Fernando's brother- and sister-in-law, García III of Navarra and his wife Stephanie of Foix, executed just a year earlier in the foundational diploma of the monastery of Santa María la Real de Nájera ${ }^{20}$ (founded in law in 1052, with the document being drawn up in 1054) (Figure. 11.2). ${ }^{21}$ It is clear that Fernando I knew this document firsthand because it was signed by him (Ferdinandus Rex confir.+) barely four days after he had caused the death of his brother García. To understand Fernando I's pretension to be recognized as the new David, ${ }^{22}$ we

19 Otto K. Werckmeister, "The Art of the Frontier: Mozarabic Monasticism," in The Art of Medieval Spain, pp. 121-32, esp. 132. The identification of this Riojan artistic genealogy is supported by the aesthetic relationship between the decorated initials in the Diurnal of Fernando I and Sancha and a collection of homilies from San Millán de la Cogolla (Madrid, Real Academia de la Historia, cod. 39, fol. 134r).

20 Diploma of the founding of the abbey of Santa María la Real de Nájera, 1054 (Madrid, Real Academia de la Historia, sig. 29o). At the bottom is the profile of the church of Santa María la Real de Nájera, between the effigies of García III and Stephanie. Prudencio de Sandoval, Catálogo de los obispos que ha tenido la santa iglesia de Pamplona, desde el año de ochenta que fue el primero della el santo martyr Fermín, su natural ciudadano (Pamplona, 1614), fols. 45v-51v; De Silva y Verástegui, "Los primeros retratos reales," pp. 259-61; Daniele Perrier, "Die spanische Kleinkunst des 11. Jahrhunderts. Zur Klärung ihrer stilistischen Zusammenhänge im Hinblick auf die Frage ihrer Beziehungen zur Monumentalskulptur," Aachener Kunstblätter $5^{2}$ (1984), pp. 29-15o, esp. 45-46; De Silva y Verástegui, "La miniatura en el Reino," pp. 362-64; De Silva y Verástegui, "Imágenes matrimoniales," pp. 581-610 (states that the image of García III is the first of a king wearing a crown in the Hispanic Middle Ages); Fernando Galván Freile, "Documento de la fundación del monasterio de Santa María de Nájera," in Sancho el Mayor y sus herederos. El linaje que europeizó los reinos hispanos (Pamplona, 2006), pp. 287-9o.

21 Fidel Fita, "Santa María la Real de Nájera. Estudio crítico," Boletín de la Real Academia de la Historia $26 / 3$ (1895), 155-98.

22 Joaquín Yarza Luaces, "La peregrinación a Santiago y la pintura y miniatura románicas," Compostelanum 30 (1985), 369-93, esp. 372-73. In addition to linking the Nájera diploma with the diurnal, he believed that to the gold of the crown and the purple of the tunic, which proclaim the imperial aspirations of the Leonese King (Díaz y Díaz, Códices visigóticos, pp. 286-87), must be added the reception of the Book of Psalms, which invoked his aspiration to be a present-day David. 
must note that García III is portrayed in the miniature as the new Solomon of his kingdom. Despite the deterioration of the diploma, one can still see that García wears a crown, cloak, short tunic, tight breeches, and high, laced boots, whereas Stephanie (the true patron of the document) wears a long tunic and veil; both have their hands raised in a gesture denoting their regal status. In the upper corners of the document are Saint Gabriel and the Virgin Annunciate.

The figures of the Virgin and Queen Stephanie resemble one another in their garments: an ankle-length skirt, a cape, and a veil over the head and supported at the shoulders. But the most conclusive point is that the image of Sancha in her book of hours is completely indebted to the miniature of the Navarrese sovereign in the Nájera diploma (Figure. 11.3) and, as a consequence, also resonates with the Virgin of the Annunciation on the latter parchment. ${ }^{23}$ We might speculate if her majesty the Leonese queen was made to resemble the Virgin, thus situating her within the lineage of David and compensating for her lack of royal attributes.

Was it during the reign of Fernando I that the king of León was first identified with the king of the animals? The coins from this period give no evidence that this symbolic and emblematic assimilation (Legionis vs. Leo) occurred and spread starting in the mid-11th century. Nevertheless, the hypothesis has been suggested by Menéndez-Pidal, who bases his theory again on the Diurnal of Fernando I and Sancha. ${ }^{24}$ If in the representations of Oton III an imperial eagle crowns his crozier, the lion's head on the tip of Fernando's staff could be a succinct and eloquent invocation of the name of his kingdom unless, that is, he is proclaiming himself a sovereign with the spirit of a lion. What is certain is that this zoomorphic representation was absent from the staffs of the kings depicted in Vigila's codex and the Codex Emilianense, so the innovation may be attributed to the miniaturist Fructuosus. In short, it is both logical and evident that the image of the Leonese royal couple brings together earlier iconographic sources with the beginnings of new and clearly symbolic elements, such as the veil and the staff of office.

23 Moralejo Álvarez, "Notas a la ilustración," p. 54. He cleverly intuits that Queen Sancha seemed to form part of an "interpolated Annunciation." The iconographic source is, in effect, found in the Annunciation in the Nájera document, as F. Prado-Vilar demonstrates in his analysis of this scene "Lacrimae rerum," 206, figs. 11a, 11 b.

24 Faustino Menéndez-Pidal de Navascués, "La imagen del rey: signos y emblemas," in Sancho el Mayory sus herederos, pp. 165-69, esp. 167; Clara Delgado Valero, "El cetro como insignia de poder durante la Edad Media," in Los clasicismos en el arte español, Actas delX Congreso del CEHA (Madrid, 1994), pp. 45-52, esp. 49. 
In December 1063, eight years after the Council of Coyanza and after the creation of the Diurnal of Fernando I and Sancha, the relics of Saint Isidore arrived in León from Seville. ${ }^{25}$ As is well known, among a myriad of sumptuous pieces, ${ }^{26}$ Fernando I commissioned two magnificent reliquaries, one in silver to act as the direct container for the holy remains (Figure. 11.4) and another of gold, gold-plated silver, and enamel to house the silver reliquary. ${ }^{27}$ The gold container was stripped of its metal and reduced to its wooden frame by Napoleon's troops during their shameful occupation of the church of San Isidoro from 1808 to $1809,{ }^{28}$ but prior to this the container had presented Christ in Majesty flanked and exalted by the apostles, according to the description left by Morales. The surviving reliquary in silver was embossed with episodes of Earthly Paradise, ${ }^{29}$ a male lay individual, and on the lid five rectangles separated by borders, with a crowned man among four beardless individuals. ${ }^{30}$ The central effigy on the lid is Fernando I surrounded by members of his court rather than by his children (figures. 11.5, 11.6);31 the man who appears on the

25 An examination of those events is to be found in: Etelvina Fernández González, "Imagen, devoción y suntuosidad en las aportaciones de Fernando I y Sancha al tesoro de San Isidoro de León," in Monasterios y monarcas. Fundación, presencia y memoria regia en monasterios hispanos medievales, ed. José Angel García de Cortázar (Aguilar de Campoo, 2012), pp. 16o-97, esp. 172-88.

26 Therese Martin, "Caskets of Silver and Ivory from Diverse Parts of the World: Strategic Collecting for an Iberian Treasury," in The Medieval Iberian Treasury in the Context of Cultural Interchange, ed. Therese Martin, Medieval Encounters 25/1 (Leiden, 2019), pp. $1-38$.

27 Ambrosio de Morales, Viage a los reynos de Leon, y Galicia, y principado de Asturias (Madrid, 1765), p. 47; Manuel Gómez-Moreno, "El Arca de las reliquias de San Isidoro," Archivo Español de Arte y Arqueología 8/24 (1932), 205-12; Perrier, "Die spanische Kleinkunst des 11. Jahrhunderts," pp. 86-91; Ángela Franco Mata, "El tesoro de San Isidoro y la monarquía leonesa," Boletín del Museo Arqueológico Nacional 9 (1991), pp. 35-67, esp. 47-52; Horst Bredekamp, and Frank Seehausen, "Das Reliquiar als Staatsform: das Reliquiar Isidors von Sevilla und der Beginn der Hofkunst in León," in Reliquiare im Mittelalter, eds. Bruno Reudenbach, and Gia Toussaint (Berlin, 2005), pp. 137-64.

28 Julio Pérez Llamazares, El tesoro de la Real Colegiata de San Isidoro de León (reliquias, relicarios y joyas artisticas) (León, 1925), pp. 115-28; Julio Pérez Llamazares, Historia de la Real Colegiata de San Isidoro de León (León, 1927), pp. 204-07.

29 Perhaps reinstalled after the restoration by Manuel Rebollo in 1847; see John W. Williams, and Daniel Walker, "Reliquary of Saint Isidore," in The Art of Medieval Spain, pp. 239-44; Fernández González, "Imagen, devoción y suntuosidad," p. 177.

30 María Jesús Astorga Redondo, El arca de San Isidoro: historia de un relicario (León, 199o), pp. 66-81.

31 The first description of this group and of another equivalent and lost group, perhaps with Queen Sancha at its centre, is found in: José Manzano, Vida y portentosos milagros del glorioso San Isidoro, Arzobispo de Sevilla y egregio Doctor y maestro de las Españas (Salamanca, 1732), pp. 380-81. For a graphic recreation of the presumed original state, 
long front of the box may also be the monarch, although he is represented with an attitude of humility and without any of his emblems (Figure. 11.7). ${ }^{32}$ The tight breeches or tibialias, the short tunic, and the chlamys with a reliquary brooch are distinct from the garments shown in the book of hours; however, the crown on the figure on the lid and the gestures are similar in the figure of the king on the cover of the reliquary and in the Diurnal. The iconographic type on the reliquary from 1063 is indebted to Carolingian (Charles the Bald), Anglo-Saxon (Athelstan), ${ }^{33}$ and Salian (Henry III the Black) imperial representations. ${ }^{34}$ In the miniature that depicts the 1040 consecration of Stavelot in the Gospels of Henry III, ${ }^{35}$ the emperor proclaims his status by wearing a crown and gold-hemmed chlamys and spurs and holding the orb and the sceptre with an eagle.

It is clear that, between the book of hours of 1055 and the reliquary of Saint Isidore of 1063 , there was a transformation in the model used to represent Fernando I, and this may be attributed to the iconic repertoire disseminated through Saxon metalwork, which in turn directly or indirectly informed the execution of Isidore's reliquary. ${ }^{36}$ The Leonese monarch's effigy, Europeanized

see: Manuel Gómez-Moreno, "El arca de las reliquias de San Isidoro de León," Archivo Español de Arte 48 (1940), 205-12.

32 This interpretation is based on: Pérez Llamazares, El tesoro, p. 125.

33 Frontispiece of Bede's Life of Saint Cuthbert: King Æthelstan (r. 924-939) presenting a copy of the book to the saint himself. Cambridge, Corpus Christi College, MS 183, fol. 1v. Malcolm Baker, "Medieval Illustrations of Bede's Life of St. Cuthbert," Journal of the Warburg and Courtauld Institutes 41 (1978), 16-49, esp. 47.

34 Stefan Weinfurter, The Salian Century: Main Currents in an Age of Transition. The Middle Ages (Philadelphia, 1999), pp. 29-30, 85-88.

35 Evangeliary of Henry III., Staats- und Universitätsbibliothek Bremen, Ms b. 21. The cape is longer in the representation of Henry III in the Golden Gospels of Henry III, also called the Codex Aureus of Speyer or Speyerer Evangeliar (El Escorial, Real Biblioteca, Cod. Vitr. 17, fol. 3r., c. 1033-1043), and very similar to that of his father Conrad II on the next folio (fol. 2v). Jürgen Vorderstemann, "Heinrichs III. Goldenes Evangeliar für den Speyerer Dom als Ausdruck des theokratischen Reichsgedankens," in Ausstellungen zum Domjubiläum (Speyer, 1980), pp. 97-103; Matilde López Serrano, El Códice Aureo. Los cuatro Evangelios. Siglo XI (Madrid, 1987), pp. 32-33. The emperor wears a longer and rigid tunic that does not reach the ankles in the Goslarer Evangeliar Codex Caesareus Upsaliensis. Uppsala, Universitetsbiblioteket, Ms C. 93, fols. 2v and 3r. See: Ulrich Krynitz, "Bilder aus dem Goslarer Evangeliar Codex Caesareus," in Codex Caesareus: das Goslarer Evangeliar Kaiser Heinrichs III., die 'Kaiserbibel' aus Uppsala (Benediktinerabtei Kloster Echternach um 1050): zum 1000. Geburtstag Kaiser Heinrichs III. in der Kaiserpfalz/Goslar (03.09.201728.02.2018: Leihgabe der Universitätsbibliothek Carolina Rediviva Uppsala/Schweden), ed. Ulrich Krynitz (Goslar, 2017), pp. 30-69.

36 The precious metalwork from Isidore's reliquary was formed in technique, repertoire, and script in the workshops of Hildesheim, according to: Peter Lasko, Ars Sacra, 80o-1200 
in the context of an ambitious cultural process that saw the commissioning of artists and artworks from the north of the continent and from the south of the Iberian Peninsula, sought to detach itself from native traditions and to place Fernando I on the same iconographic level as his contemporary German emperors. Moreover, the courtly composition of the lid - along with the image of the man without emblems on the front of the reliquary, who can perhaps also be interpreted as Fernando I, given the lack of any other more plausible option $^{37}$ - certified the sovereign's tight spatial and spiritual connection with the relics of the saint. Fernando I is at once their custodian and their devotee. In this way, he analogized himself to the Ottonian emperors who had depicted themselves as close to the divine in miniatures and metalwork, an iconographic formula that the Germans had themselves internalized from Byzantine art and political theology.

All the iconography on the silver chest remained hidden from human eyes because, as is obvious, its insertion into the lost golden chest prevented it from being seen. ${ }^{38}$ Despite the historiographical debates, I believe that the representation on the front shows Fernando Sánchez in his most strictly human dimension and completely avoids all royal references. In the narrative context of the reliquary, this man appears as a son of Adam and Eve and is, therefore, mortal and impelled to accept his sins and the penance that they bring. The body of Saint Isidore offers spiritual assistance to the king and the kingdom; in reciprocity, the monarch looks after the saint and encourages worship of him, which is dutifully discharged by all the faithful who attend the Leonese church.

This mutually beneficial relationship between the saint and the king operates on a specific bodily, pragmatic, and predictive plane. In fact, only two years after installing the relic at the main altar, at Christmas in 1065, Fernando I entered the church to consummate his ceremonial representation of the most

(Harmondsworth, 1972), pp. 48-149 (repr. Madrid, 1999, pp. 255-57); Williams Walker, "Reliquary of Saint Isidore," p. 244. For a contrasting view, see: Isidro Bango Torviso, "Relicario de San Isidoro," in Maravillas de la España Medieval, ed. Bango, pp. 228-29. The most in-depth study can be found in: José Alberto Moráis Morán, La arqueta de San Adrián y el culto a sus reliquias en el antiguo reino astur leonés (Valparaíso, 2016), pp. 212-27.

This identification is doubted by: Etelvina Fernández González, "Relicario de San Isidoro," in Sancho el Mayor y sus herederos, pp. 136-41; Etelvina Fernández González, "La imago regis y de la jerarquía eclesiástica a través de las artes plásticas (siglos IX-XII)," in Monarquía y sociedad en el Reino de León. De Alfonso III a Alfonso VII 2 (León 2007), pp. 45-96, esp. 6o.

38 José Alberto Moráis Morán, "Reliquiae recondite. Invisibilidad y expansión visual de los despojos santos en la Alta Edad Media hispana," Historia 396, 8/2 (2018), 145-87, esp. $161-66$. 
pious Christian death. The king, stripped of his regalia, cuts a penitent figure in a ritual process. The pious and devout sovereign acts out a moving scene, both as an image on Isidore's reliquary and as a physical body on the pavement of the church that he had promoted. Because, as has so often been repeated, ${ }^{39}$ the Historia legionensis (previously called silensis, $c .1115^{-1125}$ ) stated that the last days of the life of Ferdinandus rex gloriossissimus and pius were led in accordance with the death ceremony that Saint Isidore had followed in Seville in 636, according to his hagiography. Thus, on Christmas Eve, Fernando I joined the choir of clerics. The following day, he sang Christmas Matins more Toletano and attended Mass. On 26 December, he participated in four liturgical acts cultu regio ornatus cum corona capiti imposita, knelt before the altar of Saint John and the bodies of Saint Isidore and Saint Vincent, and proclaimed that his kingdom belonged to God. He removed his chlamys and his crown of precious stones, put on a hair shirt in place of his royal clothing, was anointed with ash in place of his diadem, and observed penitence for two days in the nave before dying on the third. ${ }^{40}$ The ars moriendi of the king imitated that of Saint Isidore $^{41}$ (along with those of the Ordo Penitentie from the Liber Ordinum ${ }^{42}$ as Charles J. Bishko pointed out), thus enabling him to shed his autoritas and to renounce his potestas. Voluntarily and reflexively, he chose to do this so he would be reduced to the condition of mortal man, the same condition invoked by the frontal image on Isidore's reliquary. The reliquary belonged to Ferdinand

39 Charles J. Bishko, "The Liturgical Context of Fernando I's Last Days, According to the Socalled 'Historia Silense', Hispania Sacra 17 (1964), 47-59.

40 "Et hec dicens exuit regalem clamidem qua induebatur corpus, et deposuit gemmatam coronam qua ambiebatur caput, atque cum lacrimis ecclesie solo prostratus, pro delictorum venia Dominum attentius exorabat. Tunc ab episcopis accepta penitentia, induitur cilicio pro regali indumento, et aspergitur cinnere pro aureo diademate; cui in tali permanenti penitentia duobus diebus vivere a Deo datur. Sequenti autem die que est feria tertia hora diei sexta, in qua sancti lohannis Evangeliste festum celebratur, celo inter manus pontificum tradidit spiritum." Historia Silense, ed. Francisco Santos Coco (Madrid, 1921), pp. 9o-91; Historia silense, eds. Justo Pérez de Urbel, and Atilano González Ruiz-Zorrilla (Madrid, 1959), §105-106, pp. 207-09.

41 Redemptus, Relatio de transitu beatissimi Isidori episcopi, PL, 81, 30-32. The Flors Sanctorum thus describes the death of Saint Isidore (4 April 636): after calling his friends the bishops Eparcio and John, he went to the church of Saint Vincent and covered himself with ashes and with great humility, devotion, and reverence he received the body and blood of the Lord, he prostrated himself on the floor and asked for the forgiveness of all those present and absent, in case any might have been offended. See: Bishko, "The Liturgical Context," n. 16.

42 Liber Ordinum Episcopal (cod. Silos, Arch. Monástico, 4), ed. José Janini (Silos, 1991), pp. 11316; Ángela Franco Mata, "Liturgia hispánica y marfiles talleres de León y San Millán de la Cogolla en el siglo XI," Codex Aquilarensis 22 (2006), 92-145, esp. 104-13. 
I not only because of the wealth he had invested in it but also because, through it, he entrusted his spirit to the saint.

With the same dramatic intensity, he claimed for himself and for his wife, with the inscription FREDINANDUS REX ET SANCIA REGINA (figures. 11.8, 11.9), the ivory cross that is the first example in Hispanic medieval art of a corporeal, volumetric, and triumphant Christ, albeit lacking a crown. ${ }^{43}$ The king likewise offered this distinguished piece to the altar of Saint Isidore, on the day of its consecration on 21 December $1063 .{ }^{44}$ This extraordinary reliquary cross (Figure. 11.10) enabled the monarchs to enjoy the Lord's oversight while, in the midst of their tribulations, they demonstrated their contrition and gave themselves over to his redemption, seeking to overcome the terminal hours, individual oblivion, and the Last Judgement, in the liturgical framework of the Ordo de defunctis from the Hispanic Liber Ordinum..$^{45}$ That same spirit fills the

43 Although he had already been represented in the complex Calvary scene in the Gerona Beatus (Girona, Arxiu Catedral, Ms 7, fol. 16v), produced at the monastery of Tábara (Kingdom of León) in 975. Joaquín Yarza Luaces, "Iconografía de la Crucifixión en la miniatura española: siglos X al XII," Archivo Español de Arte 47-185 (1974), 13-38, esp. 29-30; John W. Williams, The Illustrated Beatus. A corpus of the illustrations of the commentary on the Apocalypse. II. The Ninth and Tenth Centuries (London, 1994), pp. 51-64.

44 Marlene Park, "The Crucifix of Fernando and Sancha and Its Relationship to North French Manuscripts," Journal of the Warburg and Courtauld Institutes 36 (1973), 77-91. She demonstrated that the authors of the ivory cross were from the English Channel area (Saint-Bertin and Saint-Vaast), thus correcting the assertion made by: Lasko, Ars Sacra, 800-1200, pp. 149-50. From among the extensive bibliography, I would recommend: Manuel Gómez-Moreno, and Luis Vázquez Parga, En torno al crucifijo de los reyes Fernando y Sancha (Madrid, 1965); Franco, "El tesoro de San Isidoro," pp. 57-62; Raquel Gallego García, La eboraria durante el reinado de Fernando I. La perspectiva de unas artes suntuarias europeas, Ph.D. (Univ. Complutense de Madrid, 2010), pp. 155- 261. She notes that the ivory Christ was decisively influenced by the miniature, by Ottonian Anglo-Saxon ivory carving from the English Channel (thus agreeing with Marlene Park), and above all by Lothringian sumptuary art. Noemí Álvarez da Silva, La talla de marfil en la España del siglo XI (León, 2016), pp. 72-122, esp. 114-20. She discusses the artistic links suggested in all the preceding literature and distinguishes the hand of at least two artists in the execution of the cross.

45 Otto K. Werckmeister, "The First Romanesque Beatus Manuscripts and the Liturgy of the Death," in Actas del Simposio para el estudio de los Codices del 'Comentario al Apocalipsis' de Beato de Liebana 2 (Madrid, 1980), pp. 165-200, esp. 174-80. He points out that the Ordo de defunctis determined the presence of a cross together with the head of the dying man: "Hoc interdum est observandum, ut quislibet sit, ab exitu mortis usque dum ad monumentum ducatur, Semper ad caput lectuli sacram habeat crucem ... Hac explicita, precedente cruce, perducun eum ecclesiam foris, cancello posito." In addition to the Ordo in finem hominis dies invoked by other authors: Werckmeister, "The First Romanesque Beatus" pp. 167-92; Franco, "Liturgia hispánica y marfiles," pp. 108-17; Gallego, La eboraria, pp. 281-92; Álvarez da Silva, La talla de marfil, pp. 121-23. It is worth emphasizing that the 
Liber canticorum et orarum (1059) of Queen Sancha, in which she confesses her compunction aloud: "Omnia peccata mea quecunque peccavi ego misera et peccatrix Sancia" (fol. 179v). ${ }^{46}$ The sovereign Sancha, the patron and recipient of this intimate manuscript, did not commission therein any dedication page; she did not need to see herself depicted in prayer or majesty. The magnificent courtly composition of the Diurnal of Fernando I and Sancha, however, left evidence of the protocolled presentation and offering of the manuscript and, therefore, of the satisfactory fulfilment of a commission by the queen, ${ }^{47}$ who honoured and extolled her husband as caput regni. For the same reason, the Diurnal of Fernando I and Sancha was brandished as an emblem of the political programme of the moment, which not by chance was suffused with imperial connotations.

\section{Second Manifestation of the King: Figures at Prayer Seeking Intercession}

Only a few years after the production of the reliquary of Saint Isidore and the ivory cross (both 1063), King Sancho IV of Navarre, the son of the deceased king García and the nephew of Fernando I, and his wife Placencia commissioned

Liber Ordinum (Marius Férotin, Le Liber Ordinum en usage dans l'église Wisigothique et Mozarabe d'Espagne du cinquième au onzième siècle (Paris, 1904), col. 399-407) includes an Ordo de Defunctis, ad Vesperum (col. 399) that begins with some plaintive antiphons, which are faithfully reflected by the ivory cross of Ferdinand I and Sancha: "Eripe, Domine, animas nostras de morte, ut placeamus tibi in lumine uiuentium. Sono.: Redime, Domine, animas seruorum tuorum, Alleluia. Ant.: Ego sum resurrectio de uita, dicit Dominus. Qui credit in me, non morietur in eternum; sed dabo ei uitam eternam - Vers.: Deus deorum. Ant:: Veniet hora, quando mortui resurgent, Alleluia. Audient uocem Domini et procedent, Alleluia. - Vers.: A solis. Ant.: Parce nobis, Domine, qui animas amas. - Vers.: Ad te leua[ui]. Ant.: Libera nos, Fili Dei, Saluator noster, Alleluia, Alleluia. - Vers.: De tenebris. Imnus: Christe rex, mundi creator, etc ... - Amen. Vers.: Animas quiescentium."

46 Salamanca, Biblioteca General de la Universidad, ms 2668. Castiñeiras, "Libro de Horas," p. 233; Castiñeiras, "Algunos usos y funciones," pp. 74-94; Fernando Galván Freile, "El 'Liber Canticorum et Horarum' de Sancha (B.G.U.S., MS 2668): entre la tradición prerrománica y la modernidad," in Hispaniens Norden im 11. Jahrhundert, Christliche Kunst im Umbruch, eds. Achim Arbeiter, Christine Kothe, and Bettina Marten (Petersberg, 2009), pp. 248-56 (repr. in Imágenes del poder en la Edad Media. Selección de Estudios del Prof. Dr. Fernando Galván Freile, 1 (León, 2011), pp. 451-67).

47 fol. 6r: "Fredinandi Regis Sum Liber; Fredinandi Regis Necnon Et Sancta Regina Sum Liber." fol. 285: "Sancia ceu uoluit / quod sum Regina paregit / era millena nouies / dena quoque terna." Díaz y Díaz, Códices visigóticos, pp. 283-87; Galván, "El 'Liber Canticorum et Horarum' de Sancha," p. 453. 
a magnificent reliquary of silver and ivory intended to contain the relics of Saint Aemilian, the principal saint in his kingdom (c. 1064-1068). ${ }^{48}$ On the front of the La Cogolla reliquary, the circumspect humility manifested by the royal couple before Christ, ${ }^{49}$ antithetical to the expressive restraint of Fernando I, was unheard of among Hispanic royal effigies. Indeed, the couple reproduced in more than one sense the devout gestures of the Carolingian and Ottonian emperors and of the Salian emperor Henry III and his wife Agnes on their Speyerer Evangeliar (c. 1033-1043) and their Goslarer Evangeliar Codex Caesareus Upsaliensis (c.1050). However, the reliquaries of León and La Cogolla share a notable conceptual and artistic parameter: the images of the sovereigns are not only part of the narrative surface of the reliquary, but by their effigies the kings are also physically integrated into material body of the reliquary, thus establishing a relationship, both intimate and vivid, between the living patron and the venerated saint. This display of physical and spiritual immediacy and the consequent protection afforded by the patron saint strengthened the sovereign's legitimacy and his exercise of power, whether at court or at battle.

The attitude and gestures of Sancho IV and Placencia do bear compositional and formal similarities to another representation of Fernando I and Sancha, albeit one that was produced after the deaths of the Leonese monarchs: the mural painting of the Leonese dynastic cemetery, commissioned by

48 Destroyed by Napoleonic troops on 20 December 1809.

49 We know how the images of the Navarrese monarchs were displayed on the front of the chest from San Millán de la Cogolla (c. 1064-1068) thanks to the description by: Prudencio de Sandoval, Primera parte de las fundaciones de los Monasterios del Glorioso Padre San Benito (Madrid, 16o1), fol. 27r: "y la otra del Rey don Sancho puesto de rodillas, con vn letrero de marfil, y letras Goticas, que dize: Sanccius Rex supradictus. Y la otra figura es la de la Reyna doña Placencia muger deste Rey, con vn letrero de marfil encima, que dize: Divae memoriae Placentiae Reginae" (and the other of King Sancho kneeling, with an inscription in ivory and Gothic letters that says: Sanccius Rex supradictus. And the other figure is Queen Placencia, wife of this king, with an inscription in ivory that says: Divae memoriae Placentiae Reginae). See: Francisco Iñiguez, Arte Medieval Navarro 2: Arte Románico (Pamplona, 1973), lam. 28; Patrick Henriet, "Rois en prière et oracle sibyllin. Une relecture de certaines scènes du reliquaire de San Millán de la Cogolla (années 1060-1070)," Cultura y poder en la Edad Media peninsular. Studia historica. Historia medieval 33 (2015), pp. 51-67. He has corrected the titulus of the king, who according to him said: Sanccius rex supplicans. See also: Julie Ann Harris, "Culto y narrativa en los marfiles de San Millán de la Cogolla," Boletín del Museo Arqueológico Nacional 9/1-2 (1991), 69-85; Isidro Bango Torviso, Emiliano, un santo de la España visigoda, y el arca románica de sus reliquias (San Millán de la Cogolla, 2007), pp. 142-45; De Silva y Verástegui, "Imágenes matrimoniales," pp. 603-05. On another ivory plaque is the effigy of a man identified as Ranimirus Rex, meaning Ramiro of Pamplona (died 992), the great-great-uncle of Sancho IV. Sandoval, Primera parte de las fundaciones, fol. $26 \mathrm{r}$. 
their firstborn daughter, the infanta Urraca (r. 1067-1101), and painted around 109O-1095. ${ }^{50}$ The king (FREDENANDO REX) and the queen ([SAN] C [I] A) are shown kneeling at the foot of the Cross, on either side of the skull of Adam; in this way, Adam functions as a paternal intermediary between mortal man and the man-God (Figure. 11.11).

The names proclaim the patrons of the work, who are also its privileged spiritual beneficiaries. The inscriptions on both the ivory cross and the mural are arranged in such a manner as to place Fernando I and Sancha immutably at the feet of Christ, and there they remain in prayer and uninterrupted until the Parousia. The names personalize those who are offering up the prayers, (the king and queen), which gives the painted figures their identity and capacity for action. ${ }^{51}$ Together with the writing (which is always itself an image) the images of the monarchs configure them as actors who are making every effort to achieve their own salvation. In this sense, the effigies remain in action, operating as effective intercessors between the monarchs and the Redeemer. The images circumscribe and personalize the worshippers, proclaiming everything that only Christ should hear. King and queen are, in their images, just as they are in their names. Across the ivory cross and the mural, the words and figures tether the sovereigns to an atemporal present. It would have been impossible to conceive of a more intense stimulus to prayer for the monastic spectators.

The iconographic references in the mural scene at the site popularly known as the 'Pantheon of the Kings' were not limited to the cross from 1063. It should be recalled that Urraca, an artistic patron at least as exceptional as her parents, commissioned a range of exquisite works, among them a processional cross that displayed, at the feet of Christ, not only an inscription but also an image of herself kneeling, just as her parents do in the mural painting. ${ }^{52}$ Thus, for a third

50 Gerardo Boto Varela, "In Legionenssy regum cimiterio: la construcción del cuerpo occidental de San Isidoro de León y el amparo de los invitados a la Cena del Señor," in Monumentos singulares del románico. Nuevas lecturas sobre formas y usos (Aguilar de Campoo, 2012), pp. 93-135.

51 Vincent Debiais, "Mostrar, significar, desvelar. El acto de representar según las inscripciones medievales," Codex Aquilarensis 29 (2013), 169-186; Noemí Álvarez da Silva, "La inscripción como imagen de poder en la Edad Media. El caso de Fernando I de León y su esposa doña Sancha," in Las artes y la arquitectura del poder. XIX CEHA, ed. Víctor Mínguez Cornelles (Castellón, 2013), pp. 1787-803.

52 Margarita M. Estella Marcos, La escultura del marfil en España: románica y gótica (Madrid, 1984, repr. Valladolid, 2012), p. 26; Manzano, Vida y portentosos milagros del glorioso San Isidoro, p. 383: "Entre las Reliquias que a Cristo nuestro Redentor, pertenecen, debe enumerarse el Crucifixo, que se adora en el Camarín, y antes estaba en lo alto de la capilla mayor. Esta Sacratísima Imagen, fue dádiva de Doña Urraca, hija de Don Fernando el Magno, la materia del Crucifixo, es de marfil, varnecido a lo antiguo de encarnación, y en 


\section{time, Leonese art imitated a formula first tried out in Navarrese art some years}

la Cruz, está el Señor pendiente de cuatro clavos, dos en las manos y otros dos en los pies, que están separados, uno de otro. ... El recto de la Cruz donde está pendiente, es de chapa de oro y plata, esmaltada con muchas piedras grandes, y de mucho valor, que alrededor están repartidas. El pie donde se asientan los pies, que están separados, es de chapa de oro: debaxo de él, una efigie de oro, de medio relieve, de Doña Urraca con esta inscripción: Urraca regis Ferdinandi filia et Sanciae Reginae donavit. La altura de la Cruz es de dos varas, y media, y lo ancho de los brazos de vara y media." (Among the relics that belong to Christ our Saviour are the Crucifix, which is worshiped in the Camarín and which was in the highest part of the main chapel. This most holy image was generously given by Lady Urraca, daughter of Fernando the Great, the Crucifix is of ivory, varnished in the old style, and on the Cross is the Lord hanging by four nails, two in his hands and another two in his feet, which are separate from each other. ... The upright of the Cross from which he hangs is of sheet gold and silver, enamelled and decorated all over with many large stones and of great value. The foot of the Cross where his feet are is of sheet gold: below him, a gold figure, in half relief, of Lady Urraca with the following inscription: Urraca regis Ferdinandi filia et Sanciae Reginae donavit. The height of the Cross is two and a half yards and the width of the crosspiece is one and a half yards). See: Franco Mata, "El tesoro de San Isidoro y la monarquía leonesa," pp. 64-65. She refers to: Manuel Risco, Iglesia de León, y monasterios antiguos y modernos de la misma ciudad (Madrid, 1792), pp. 146-47, who states: "Debaxo de los pies del crucifixo se lee esta palabra: Misericordia, y luego: Vrracca Fredinandi Regis Et Sancia Reginia Filia; y en la parte inferior de la Cruz se representa la misma Doña Urraca arrodillada, juntas, elevadas, y extendidas las manos, repitiéndose su nombre, cuyas letras comienzan sobre su cabeza, y baxan por delante, extendiéndose casi tanto como la figura." (Beneath the feet of the Crucifix can be read the word Misericordia, followed by Vrracca Fredinandi Regis Et Sancia Reginia Filia; and on the lower part of the Cross is represented Lady Urraca, kneeling with her hands together, raised and extended, repeating her name, whose letters start above her head, and go down the front, extending almost as far as the figure). The testament of Bishop Pelayo de León, written in November 1073. Manuel Risco, España Sagrada, t. 36: Memorias de la Santa Iglesia esenta de León (Madrid, 1787), Apend. 28, pp. LIX-LXI; Colección documental del archivo de la catedral de León (1032-1109) 4, ed. José Manuel Ruiz Asencio (León, 1990), doc. $\mathrm{n}^{\circ} 1190, \mathrm{pp} .439-47$, esp. 443-44. It declares that the infanta Urraca donated to the cathedral a crucifix clearly produced before 1073: Composui lignum Domini crucifixo decoratum. Jean-Marie Sansterre, and Patrick Henriet, "De l'inanimis imago à l'omagem mui bella. Méfiance à l'égard des images et essor de leur culte dans l'Espagne médiévale (VIIe-XIIIe siècle)," Edad Media. Revista de Historia 10 (2009), 37-92, esp. 56-57. There is no record that this cross in the cathedral included an effigy of the infanta kneeling at the feet of the Lignum Crucis, as in the cross donated to Saint Isidore. Nor is it possible to infer a chronology for the Isidoran cross by Urraca. At a guess, it was produced before the mural paintings, not very distant in time from the production of the celebrated chalice of Lady Urraca: In Nomine Domini. Vrraca Fredinandi. José Alberto Moráis Morán, "Pervivencias de la antigüedad clásica en la Edad Media hispana. El spolium in se: a propósito del cáliz de doña Urraca," in Perfiles de Grecia y Roma. Actas del XII Congreso Español de Estudios Clásicos (Madrid, 2009), pp. 904-27; Therese Martin, "Mujeres, hermanas e hijas: el mecenazgo femenino en la familia de Alfonso VI," Anales de historia del arte 2 (2011), 147-79, esp. 149-54. 
earlier. ${ }^{53}$ This trajectory meant that not until the last third of the 11th century did the Hispanic kings begin to bow down in effigy before the divinity, much later than had been the case with the Carolingian and Ottonian emperors. ${ }^{54}$

In the cemetery of the Leonese kings, the mural is not a representation sensu stricto of Fernando I and Sancha, as the miniature in the book of hours clearly aspires to be, but rather an image invoking a perpetual prayer that is more visual than intoned, or perhaps operating through synaesthesia. The composition, with the two protagonists at the foot of the Cross, did not merely lay down a ritual approach to prayer that could be followed by the community. It, moreover, actively incentivized prayer because, under the auspices of Urraca, clerics and nuns took on the task of interceding for the salvation of the kings and their bloodline. The painting, in fact, operates beyond action and time to suggest the perpetual nature of the demeanour of Fernando I and Sancha before Christ the Redeemer.

The purple colour of the tunics of both husband and wife (Figure. 11.12) marks them as being of imperial lineage. Indeed, by the time the paintings were executed, their son and successor had for years been calling himself Imperator totius Hispaniae, as indeed had the Pope. ${ }^{55}$ The same painted colour can also be seen on three blocks of stone dressed in red a few courses beneath the painting, with a colour very similar to the 'purple' red of clothes' king and queen. These ashlars perhaps indicate the original location of the tombs of Fernando I and Sancha, that is, close to the wall at the foot of the painting that prayed for them in perpetuity, adjacent to the walls of the residence of God and the entrance to heaven (Porta Coeli).${ }^{56}$ According to the description by

53 This circumstance is suggested for the royally commissioned metalwork objects, from Nájera to León: Moráis Morán, La arqueta de San Adrián, p. 211.

54 Henriet, "Rois en prière et oracle sibyllin," p. 53.

55 Since 1077. All the data can be found in: Julia Montenegro, and Arcadio del Castillo, "Los títulos de los reyes de León en los documentos medievales como reflejo de la continuidad del reino visigodo de Toledo," Estudios de Historia de España 13 (2011), 13-36; Hélène Sirantoine, Imperator Hispaniae. Les idéologies impériales dans le royaume de León (IXe-XIIe siècles) (Madrid, 2012). For a sample of the typical way that sibling emperors were represented at the feet of Christ, see the ivory book cover (980-983) featuring Otto II, Theophanus, and Otto III (Milano, Civiche Raccolte d'Arte Applicata del Castello Sforzesco). A contextualization of the origin of the new imperial iconographies can be found in: Hagen Keller, "Das neue Bild des Herrschers. Zum Wandel der 'Herrschaftsrepräsentation' unter Otto dem Großen," in Ottonische Neuanfänge. Symposion zur Ausstellung 'Otto der Große, Magdeburg und Europa,' eds. Bernd Schneidmüller, and Stefan Weinfurter (Mainz, 2001), pp. 189-211.

56 Rose Walker, "The Wall Paintings in the Panteon de los Reyes at Leon: A Cycle of Intercession," The Art Bulletin 82/2 (2000), 200-25; Manuel Castiñeiras González, "El 
Morales, ${ }^{57}$ in the 16th century the tombs of Fernando and Sancha were immediately beneath the depiction of Calvary and, therefore, adjacent to the red ashlars.

The Calvary composition in the dynastic cemetery in the church of Saint Isidore maintains an unquestionable relationship with the depiction of the same subject in the central scene on the lid of the Holy Ark in the cathedral of Oviedo (c.1095-1100), the largest silver reliquary from the Romanesque period. The latter, and I repeat that I am specifically referring to the axial composition on the lid, only differs from the mural in the absence of the monarchs at the feet of Christ. ${ }^{58}$ My interpretation is that, at the end of the 11th century, the artistic workshops in Oviedo and León exchanged certain compositional models. This is not conclusive on my part, nor do I wish to rule out other theories (for example, Moralejo Álvarez drew parallels with Anglo-Norman and English manuscripts $)^{59}$ in pointing out that artistic elements were shared across the Cantabrian mountain range, that is, between León and Oviedo. It is also obvious that the artist who depicted Alfonso II in the Liber Testamentorum, ${ }^{60}$ where he kneels in prayer before a Gloria identical to that on the front of the Holy Ark, had been aware of the Leonese composition of the king kneeling in prayer before a triumphant Christ and supported by the royal men-at-arms. The similarity is clear evidence of the itinerary of these iconographic borrowings. ${ }^{61}$

The Pantheon of the Kings was the setting for the perpetual tomb of the king. The lid of the tomb of Fernando I, destroyed during the Napoleonic invasion, was inscribed with an epigraph during the first decades of the 13th century, a century and a half after his death. The text confirmed the identity of the cadaver confined within and commemorated Fernando I's extensive and victorious dominion over the Muslims as well as his traslatio of Saint Isidore's relics to the church before whose doors his tomb and those of his family were

Programa Enciclopédico de la Puerta del Cielo en el Panteón Real de San Isidoro de León," Compostellanum 45/3-4 (2000), 657-94.

57 Morales, Viage, p. 43 .

58 This relation is not supported by: César García de Castro, El Arca Santa de la catedral de Oviedo (Aguilar de Campoo, 2017), p. 35. He considers the composition as a whole rather than the iconographical inspirations for its parts. I agree with the chronology that he puts forward for the work (p. 84), which is the last decade of the 11th century, thus making it strictly contemporary with the paintings in the Pantheon of the Kings.

59 Serafín Moralejo Álvarez, "Les Arts somptuaires hispaniques, aux environs du 110o," Les Cahiers de Saint-Michel de Cuxa 13 (1982), 285-310, esp. 288-289.

6o Oviedo, Archivo de la Catedral, Ms 1, fol. 4v. Joaquín Yarza Luaces, "Las miniaturas del Liber Testamentorum," in Liber Testamentorum Ecclesiae Ovetensis (Barcelona, 1995), pp. 147-230.

61 John W. Williams, "Liber Testamentorum," in The Art of Medieval Spain, p. 247. 
installed. Although the structure of the royal cemetery was commissioned by his daughter Urraca, this epigraph elevated Fernando to the status of intellectual author and promoter of the "petrification" (as the burial inscription literally says) of the church of Saint Isidore. This sepulchral text reproduced part of the information present in the stone situated in the tympanum of the early connecting door between the cemetery and the church. ${ }^{62}$ Temple, tomb, mural painting, and sepulchral epigraph constituted the four lasting imagines of Fernando I in the Leonese mausoleum. They were four visible and tangible expressions that operated in a symbiotic and circular manner: the painting adhered to the wall, and the lid supported the traced inscription, which in turn attributed to the sovereign the authorship and ownership of the building and the cemetery. Although each monodically intones the memory and figure of the king, they also operate complementarily as four witnesses augmenting and strengthening each other's encomiastic declarations.

Of Fernando I's three sons, it was the second, Alfonso VI, who for different reasons and favourable circumstances was able to take control of his father's entire kingdom. He also managed to expand its frontiers and, in 1085, to take the emblematic city of Toledo, the political and ideological capital of the Visigothic Kingdom. ${ }^{63}$

62 "H. E. TUMUlatus fernandus Magnus ReX totius hispaniae. Filius SANCTII REGIS PIRENAEORUM ET TOLOSAE. ISTA TRANSTULIT CORPORA. SANCTORUM IN LEGIONE BEATI ISIDORI ARCHIEPISCOPI AB HISPALI VICENTIIMARTYRIS AB ABELA. ET FECIT ECCLESIAM HANC LAPIDEAM. QUAE OLIM FUERAT LUTEA, HIC PRAELIANDO FECIT SIBI TRIBUTARIOS OMNES SARRACENOS HISPANIAE ET CEPIT COLIMBriam, LAMEgo, VESEO, ET ALIAS. ISTE Vi CEPIT REgNA GARSiAe ET VEREMUDI. OBIIT VI K. JANUARII. ERA MCIII." The petrification of the church, indeed a rhetorical topos inherited from Suetonius, had been proclaimed earlier $(c .1075)$ in the inscription on the former western door: "HANC QUAM CERNIS AULAM SCI IOHANNIS BB OLIM FUIT LUTEAM QUAM NUPER EXCELLENTISSIMUS FREDENANDUS REX ET SANCI REGINA EDIFICAVERUNT LAPIDEAM TUNC AB URBE ISPALI ADDUXERUNT IBI CORPUS SANCTI ISIDORI AEPI ... IPSIUS ANNO PREFATUS REX ... OBIIT ... ERA TCIII a SANCi REginA DeOdicAta PEREgit." See: Gerardo Boto Varela, "Morfogénesis espacial de las primeras arquitecturas de San Isidoro. Vestigios de la memoria dinástica leonesa," in Siete maravillas del románico español (Aguilar de Campoo, 2009), pp. 153-91, esp. $184-88$.

63 From the enormous quantity of literature on this matter, I limit myself to citing Andrés Gambra Gutiérrez, Alfonso VI: Cancillería, Curia e Imperio (León, 1997); Antonio Linage Conde, Alfonso VI, el rey hispano y europeo de las tres religiones: 1065-1109 (Gijón, 
Alfonso VI adopted an ecclesiastic policy whereby he conferred abbeys in his kingdom to Cluny and thus allowed the order to become established and to expand into Castile. ${ }^{64}$ At the same time, he decreed in Burgos in 1080 that the Hispanic liturgy should be replaced by the Roman one. ${ }^{65}$ Both of these strategies were intended to and succeeded in Europeanizing his kingdom and in the chancery of Pope Gregory VII were looked upon as an ecclesiological unification. In the same vein, he sought to increase the veneration of the Holy Ark of Oviedo ${ }^{66}$ and, above all, of Saint James (Santiago), being aware of the economic and political benefits that would accrue from his kingdom being host to such an extraordinary spiritual goal. With these intentions and in collaboration with Bishop Diego Peláez (1070-1088), Alfonso VI laid the foundations of the enormous and majestic Romanesque cathedral of Santiago de Compostela in 1075 .

During the construction of the ambulatory, the prelate reserved the axial chapel, dedicated to the Saviour, for celebrating the episcopal offices. Meanwhile, the so-called Concordia de Antealtares (1077), an agreement signed by Bishop Peláez and the abbot of the monastery of San Paio de Antealtares, Saint Fagildo, ceded to the monastic community the right to worship in the chapel of Saint Peter. ${ }^{67}$ Between the two shrines, a small entrance named Antealtares was constructed for use by the Benedictine monks and probably also by the secular clerics close to Peláez; it is less likely that it was used by pilgrims, who continued to enter directly from the church constructed by Alfonso

2006); Alfonso VIy su Época, los precedentes del reinado (966-1065), ed. Etelvina González (León, 2007); Alfonso VI y su época II: los horizontes de Europa (1065-1109), eds. Etelvina Fernández González, and Javier Pérez Gil (León, 2008); Carlos Estepa Díez, Alfonso VIy su legado: actas del congreso internacional (León, 2012).

64 Carlos Reglero de la Fuente, "La renovación cluniacense del benedictinismo: San Isidro de Dueñas (1073-1228)," in Los grandes monasterios benedictinos hispanos de época románica: (1050-1200), eds. José Ángel García de Cortázar, and Ramón Teja (Aguilar de Campoo, 2007), pp. 59-86; Carlos Reglero de la Fuente, Cluny en España: los prioratos de la provincia y sus redes sociales (1073-c. 1270) (León, 2008); Carlos Reglero de la Fuente, "La Crónica najerense, Santa María de Nájera y Cluny," e-Spania 7 (2009). Accessed 2019 Nov 21; Carlos Reglero de la Fuente, "El Camino de Santiago, Cluny y la monarquía leonesa," in Desperta Ferro. Arqueología e Historia 6 (2016), 46-51.

65 Juan Pablo Rubio, "Introducción del Rito Romano y reforma de la Iglesia Hispana en el siglo XI: de Sancho III el Mayor a Alfonso VI," in La reforma gregoriana en España, ed. Nicolás Álvarez (Madrid, 2011), pp. 55-76.

66 Rose Walker, "Becoming Alfonso VI: the king, his sister and the 'arca santa' reliquary," Anales de historia del arte 2, 391-412.

67 Fernando López Alsina, "La Concordia de Antealtares," in Santiago, Camino de Europa, Culto y Cultura en la Peregrinación a Santiago de Compostela (Santiago de Compostela, 1993), p. 259. 
III. It is clear that this entrance, in addition to providing access, also offered an initial view of the liturgical space in the ambulatory. It is for this reason that the issue I wish to discuss regarding this building and the image of the king within it must consider the capitals' layout, themes, and inscriptions.

Any analysis of the poetry and pragmatics of the sculptural iconography in the Compostelan ambulatory must inevitably give priority to that which represents Bishop Pelaéz (Figure.11.13) and Alfonso VI. ${ }^{68}$ They each have a privileged location, though they are not situated opposite one another nor symmetrically: the king occupies the left side of the entrance arch to the chapel of the Saviour; the bishop is in the ambulatory turned $90^{\circ}$ to the west of the position of the king's capital, supporting the transverse arch immediately to the right of the aforementioned entrance arch. This arrangement has been the subject of previous studies, which have primarily examined the appearance of the sculpted images from a frontal perspective - from the axis of the ambulatory and the chapel of the Saviour, respectively, a position from which it is not possible to see the king and the bishop simultaneously. My approach, however, considers the dynamic movement through the entrance and the transversal angles of vision that enable one to view, at once, the nearest images and those farthest away (Figure. 11.14). ${ }^{69}$ From this vantage point, one is able to better appreciate the keenly conceived visual strategy that structured the thematic layout of the ensemble.

The proximity and compositional and textual similarity between the two reliefs indicate that the cathedral was a project promoted by the (inextricable) political and ecclesiastical governments. The image of Bishop Peláez is reduced to an abstract expression of his soul, without any episcopal attributes. It might be said that Peláez already aspired to, and perhaps even anticipated, a celestial existence while he was exercising his duties as prelate. In a symmetrical composition, he is flanked by two interceding angels who hold up

68 Although I have no wish to neglect the narrative wealth of the other capitals in the chapel of the Saviour and the ambulatory, in this article I must limit myself to these two. An analysis of the whole ensemble is in: Victoriano Nodar Fernández, "Imágenes para el príncipe, imágenes para el monje. Función y decoración de la cabecera de la catedral de Santiago de Compostela (1075-1101)," Codex Aquilrensis 27 (2011), 39-54; En el principio: Génesis de la Catedral Románica de Santiago de Compostela. Contexto, construcción y programa iconográfico, ed. José Luis Senra (Santiago de Compostela, 2014), pp. 165-201.

69 I examined this question in: Gerardo Boto Varela, "Hitos visuales para segmentar el espacio en la iglesia románica. La percepción transversal de las naves y la trama de los umbrales intangibles," in La imagen en el edificio románico: espacios y discursos visuales, ed. Pedro Luis Hueta Huerta (Aguilar de Campoo, 2015), pp. 205-42. 
his phylactery, which, in the most contemporary propagandistic papal terms, bears the legend "TEM PORE PRESVLIS DIDACI INCEPTVM HOC OPUS FVIT."70

The figure of the consecrated king is hieratical. Appearing in body and soul, he wears a crown, holds two keys, and is flanked by two angels who glorify his pious founding act through the inscription in a phylactery: "REGNANTE PRINCIPE ADEFONSO CONSTRVCTUM OPUS." The capital shows the monarch not only as the custodian of the entrance to the house and of the reliquary of the apostle but also as a Solomon-figure blessed by Christ. In this ritual context, the image of the king - visible to the monks, canons, and pilgrims who moved around the ambulatory - was a figure of the regnum legionensis as well as a declaration of Alfonso vi's interest in building the shrine that was intended to be a pilgrimage site and the primary link between his dominions and the rest of Christendom.

On an architectural and three-dimensional scale, the capital affirms the intimacy between the king and the Saviour, which is carried through in the chapel and at the altar that bears the latter's name. Alfonso vi thus manifested aspirations similar to those declared by his parents on the ivory cross. However, the sovereign author of the cathedral did not seek to accede to God in the tormented moment of death but rather at a triumphant moment during his reign, namely three years after having obtained the crown of León and Castile and in the same year in which he presided over the great council. Privileged by his connection with the angels, in a historical present that predicted an eschatological future, Alfonso prays to God and, at the same time, demands that men pay tribute to him for having founded the new cathedral. Indeed, the memory of him is brought back to life and is made effective through the reception of the capital by the reader-spectator. We can even go a little further, albeit cautiously. As has been reiterated, the centre of the ambulatory of the cathedral of Compostela is a topographical transposition of the iconography of the Transfiguration (with the altar of Christ in the centre, the altars of Peter and John on either side of Christ, and the altar of Saint James at Christ's feet).

70 The wording of the epigraph, not at all localistic, invokes Peláez on terms that were particularly prestigious at that time. At the instigation of Pope Alexander II and Abbot Dominicus, in 1072 the Lateran cloister received an inscription whose three lines read: "HOC FVIT INCEPTVM RENOVARI TEMPORE TEMPLVM / VRBIS ALEXANDRI ROMANi pResvlis anni / annvs ERAT dVodenvs et ipse Secvndvs." Sible de Blaauw, "A mediaeval portico at San Giovanni in Laterano: the Basilica and its ancient conventual building," Papers of the British School at Rome 58 (1990), 299-316, esp. n. 52; Peter Cornelius Claussen, Die Kirchen der Stadt Rom in Mittelalter 1050-1300, A-F (Stuttgart, 2002), p. 178. It can be inferred that the bishop of Compostela sought to invest himself with authority through the prelate of Rome and the prestige of his cathedral. 
Into that three-dimensional Transfiguration, King Alfonso VI is admitted as an exceptional co-protagonist, through his image in the capital.

Only from the entrance to Antealtares can one simultaneously observe the capital of the bishop (close up) and the king (long shot). From this privileged viewpoint, the spectator can read, in the same moment, a part of the bishop's inscription, "DIDACI INCEPTVM HOC OPUS FVIT," and a segment of that of the king, "PRINCIPE ADEFONSO CONSTRVCTUM." From no point in the cathedral can one read the totality of both epigraphs; nor are the epigraphs fragmented beyond legibility when seen from any vantage point. Regarding the complementary nature of the legible parts of the epigraphs, we can see that the "opus" that remains out of the field of view on the king's capital is compensated by the "opus" of Diego. The spectator reads and is reminded in a single visual stroke that the work was initiated by Diego and constructed by Alfonso and that this is why they both gained access to the Kingdom of God and a retinue of angels. In my opinion, this vantage point within the church is not merely circumstantial, which is to say, it is not a coincidence that has been noticed in the present but was not intended by the authors of the work. The superimposition of the two protagonists, in the context of the ecclesiastic reforms of Gregory VII and the incipient changes to the liturgy, allowed the spectator not only to see but to become aware of the presence of the governor of the Regnum in the house of the Sacerdotium, that is, a sovereign (artifex, almost opifex) in the service of Christ and his apostle. In the end, the portrait of Alfonso vi in the Historia legionensis $\left(c .1115^{-1125}\right)^{71}$ would not differ in substance from the proclamation in carved stone in the ambulatory of a shrine that beckoned forth the whole of Christianity.

Apart from Compostela, we have no other surviving images of Alfonso vI while he was alive, except those on his coins. After the tremisses minted by Witiza (r. 700-709), which showed a frontal effigy of him, the face of a monarch would not be featured on coinage again until the first half of the 11th century (Figure. 11.15)..$^{72}$ The coins of Alfonso, with the locative "TOLETA" on

71 Historia Silense, ed. Santos Coco, p. 7. Georges Martin, "Ordoño Sisnández, autor de la Historia legionensis (llamada silensis). Notas histórico-filológicas sobre un ego fundador," e-Spania 14 (2012) Accessed 2019 Oct 12; Alberto Montaner Frutos, "Presencia y ausencia de Alfonso VI en la Historia Legionensis (hactenus Silensis nuncupata)," e-Spania 14 (2012) Accessed 2019 Oct 12.

72 Aside from other questionable coins, the obolo minted in Girona shows a frontal effigy of Ramon Berenguer I; see: Serrano, Effigies Regis Aragonum, p. 38. It is a matter of speculation whether the coin was inspired by Byzantine or late-Visigothic mints. The effigy of the king was used on the coins of Sancho Ramírez, in profile and without a crown, starting possibly in the 107os. Serrano, Effigies Regis Aragonum, pp. 27-32. If this is the case, 
the reverse like those of the Visigoths, ${ }^{73}$ portray him using the same graphic resources as later Visigothic pieces. One type shows the geometric head faceon, crowned and with a pearled circle delineating the field of the image; on others, the king is depicted in profile, crowned, between a sword and a cross. ${ }^{74}$ Alfonso vi was able to unite himself with the Gothic lineage of the Historia Legionensis through the strength of such acts as taking Toledo. From then on, he claimed himself to be the sole heir to the truncated Visigoth kingdom. The frontal effigy was used for his daughter Urraca's royal mint, as a legitimating resource inherited from her father. ${ }^{75}$

As in all medieval contexts, the image of Hispanic kings, first in Navarre and later in León, was used from the 1oth to the mid-11th century for a specific and instrumental purpose. The sovereign was depicted in different postures: in the middle of the 11th century, he was shown in a standing pose, mostly in manuscripts meant for private use and on reliquaries that were not accessible to general audiences. Such images aimed to bear visual witness to both the king's role as owner or donor of objects belonging to sacred treasuries and to the

Ramírez's minters would anticipate those working for Alfonso vi by a decade and a half in the way they used the face.

73 Around 1088, they started to employ a copper-silver alloy to make Christian coins (dineros and obolos containing approximately $30 \%$ silver). The first type bears the legend "ANFVS REX" and the Cross on the obverse, and "TOLETVM" and rings and stars on the reverse. In addition to their late-Visigothic lineage, these coins incorporated features from Carolingian coinage.

74 José María de Francisco Olmos, "El nacimiento de la moneda en Castilla: de la moneda prestada a la moneda propia," in IJornadas Científica sobre Documentación jurídico-administrativa, económico-financiera y judicial del reino castellano-leonés, siglos X-XIII (Madrid, 2002), pp. 303-46; León Hernández-Canut Fernández-España, "El primer retrato regio en la moneda castellana," in XIII Congreso Internacional de Numismática 2, eds. Carmen Alfaro Asins, Carmen Marcos Alonso, and Paloma Otero Morán (Madrid, 2005), pp. 1199205; Antonio Roma Valdés, Emisiones monetarias leonesas y castellanas de la Edad Media. Organización, economía, tipos y fuentes (Madrid, 2010), pp. 11-28, 155-63; Manuel Mozo Monroy, and Francisco Javier García Montes, "Aporte histórico y documental sobre el dinero de busto godo de Alfonso VI, rey de León y Castilla," Gaceta Numismática 180 (2011), 67-82; Manuel Mozo Monroy, and Francisco Javier García Montes, "Primeras labras de vellón acuñadas en Toledo (ss. XI-XII). Propuesta de interpretación iconográfica," Parva Urbs o (2009), 16-18.

75 Jitske Jasperse, "Manly Minds in Female Bodies: Three Women and their Power through Coins and Seals," Arenal: Revista de historia de mujeres 25/2 (2018), 296-321, esp. 298-303. 
latter's worship-worthiness. In the last quarter of the 11th century, the ruler came to be rendered in a kneeling posture with an attitude of humble prayer in mural paintings decorating structures associated with a monastic enclosure, which could be accessed only by local monks and the royal family. By that time, kings were also visually glorified in the medium of sculpture in religious spaces visited by pious believers and pilgrims, as in the ambulatory of the cathedral of Santiago de Compostela. Furthermore, from the end of the 11th century all members of society became acquainted with the ruler's image, inasmuch as it was displayed on coins in either a frontal pose or in profile, but always in a definitely schematic way.

Given their wide circulation and accessibility, coins were invested with special meanings and were often meant to convey specific messages, such as about the king's merits in reconquering the mythical city of Toledo, the political aspirations and destiny of the kingdom, the main military and political triumphs of Alfonso VI, and the pursuit of his wish to be recognized as Imperator Totius Hispaniae.

There is no record of the monarch's image being used on altar frontals in either Nájera or León, as happened in the lands of the Holy Roman Empire. It was also absent from funerary monuments prior to Blanche of Navarre, whose tomb was sculpted by Leodegarius in 1157. Eleventh-century patrons did not manifest any special interest in being depicted with a clearly discernible, individualized facial appearance. Consequently, in addition to the regalia denoting the sovereign's status, the inscriptions bearing their names, and starting from around 1125-1130 also Leonese heraldry, revealed their individual identities.

Images of kings and queens were disseminated also after their deaths, without any special effort to keep visual records of their physical appearances. Their idealized faces were either repeated on coins or recreated and reshaped in collective, dynastic images. This memorializing mode would emerge in pictorial form in the painting in the Pantheon of the Kings and even more so in the cartularies of Oviedo (Liber Testamentorum) and Compostela (Tumbo A); by the mid-12th century, it also characterized the monumental sculpture of façades. ${ }^{76}$

76 Concepción Cosmen, and José Alberto Moráis Morán, "Renovación e internacionalización en la escultura románica del reino de León a mediados del siglo XII: Santa María de Carracedo," in Vestir la arquitectura: XXII CEHA 1, ed. René Payo (Burgos, 2019), pp. 34-39; José Alberto Moráis Morán, and Concepción Cosmen, "La desaparecida portada románica del monasterio de Santa María de Carracedo (León)," Anuario De Estudios Medievales 50/1 (2020), 231-266. 
The multiplication of royal representations and their propagation through coinage and seals enabled sovereigns to be remembered or made present in places other than their burial sites. Indeed, from the 11th century onwards, royal images were disseminated far from the places of major symbolic importance for the collective memory of the kingdom such as dynastic cemeteries and the archives of monasteries and cathedrals: $:^{77}$ they started circulating in the hands of their subjects and were put on public display on church façades and cloister walls.

\section{Acknowledgements}

For their invaluable contributions, my thanks go to Marta Serrano-Coll, José Alberto Moráis Morán, César García de Castro, and Alejandro García Avilés.

\section{Bibliography}

\section{Secondary Sources}

Alfonso VI y su Época, los precedentes del reinado (966-1065), ed. Etelvina González (León, 2007).

Alfonso VI y su época II: los horizontes de Europa (1065-1109), eds. Etelvina Fernández González, and Javier Pérez Gil (León, 2008).

Álvarez da Silva, Noemí, "La inscripción como imagen de poder en la Edad Media. El caso de Fernando I de León y su esposa doña Sancha," in Las artes y la arquitectura del poder.XIX CEHA, ed. Víctor Mínguez Cornelles (Castellón, 2013), pp. 1787-803. Álvarez da Silva, Noemí, La talla de marfil en la España del siglo XI (León, 2016).

Assmann, Jan, Das kulturelle Gedächtnis: Schrift, Erinnerung und politische Identität in frühen Hochkulturen (Munich, 1992).

Astorga Redondo, MaríaJesús, El arca de San Isidoro: historia de un relicario (León, 199o).

77 Mnemotopia, that is, the generation of places that create, release, and guard a memory, is a concept put forward by the sociologist Maurice Halbwachs; see La Topographie légendaire des Évangiles en Terre sainte. Étude de mémoire collective (Paris, 1941; repr. and eds. Marie Jaisson, Danièle Hervieu-Léger, Jean-Pierre Cléro, Sarah Gensburger, and Éric Brian, Paris, 2008); Maurice Halbwachs, La mémoire collective (Paris, 1950). The concept was discussed by the Egyptologist Jan Assmann; see Das kulturelle Gedächtnis: Schrift, Erinnerung und politische Identität in frühen Hochkulturen (Munich, 1992), pp. 34-47. Regarding the relevance of Halbwachs's thought, see: Paul Sabourin, "Perspective sur la mémoire sociale de Maurice Halbwachs," Sociologie et sociétés 29/2 (1997), 139-61. 
Baker, Malcolm, "Medieval Illustrations of Bede's Life of St. Cuthbert," Journal of the Warburg and Courtauld Institutes 41 (1978), 16-49.

Bango Torviso, Isidro, "Relicario de San Isidoro," in Maravillas de la España Medieval. Tesoro sagrado y monarquía, ed. Isidro Bango (Madrid, 2001), pp. 228-29.

Bango Torviso, Isidro, Emiliano, un santo de la España visigoda, y el arca románica de sus reliquias (San Millán de la Cogolla, 2007).

Bishko, Charles J., "The Liturgical Context of Fernando I's Last Days, According to the So-called 'Historia Silense', Hispania Sacra 17 (1964), 47-59.

Böse, Kristin, Von der Rändern Gedacht. Visuelle Rahmungsstrategien in Handschriften der Iberischen Halbinsel (Cologne, 2019).

Boto Varela, Gerardo, "Sobre reyes y tumbas en la catedral de León. Discursos visuales de poder político y honra sacra," in La Catedral de León en la Edad Media, eds. Joaquín Yarza, María V. Herráez, and Gerardo Boto (León, 2004), pp. 305-65.

Boto Varela, Gerardo, "Morfogénesis espacial de las primeras arquitecturas de San Isidoro. Vestigios de la memoria dinástica leonesa," in Siete maravillas del románico español (Aguilar de Campoo, 2009), pp. 153-91.

Boto Varela, Gerardo, "In Legionenssy regum cimiterio: la construcción del cuerpo occidental de San Isidoro de León y el amparo de los invitados a la Cena del Señor," in Monumentos singulares del románico. Nuevas lecturas sobre formas y usos (Aguilar de Campoo, 2012), pp. 93-135.

Boto Varela, Gerardo, "Hitos visuales para segmentar el espacio en la iglesia románica. La percepción transversal de las naves y la trama de los umbrales intangibles," in $L a$ imagen en el edificio románico: espacios y discursos visuales, ed. Pedro Luis Hueta Huerta (Aguilar de Campoo, 2015), pp. 205-42.

Bredekamp, Horst, and Seehausen, Frank, "Das Reliquiar als Staatsform: das Reliquiar Isidors von Sevilla und der Beginn der Hofkunst in León," in Reliquiare im Mittelalter, eds. Bruno Reudenbach, and Gia Toussaint (Berlin, 2005), pp. 137-64.

Castiñeiras, Manuel, "Algunos usos y funciones de la imagen en la miniatura hispánica del siglo XI: los Libros de Horas de Fernando I y Sancha," in Congresso Peninsular de História da Arte. Propaganda \& Poder (Lisboa, 200o), pp. 74-94.

Castiñeiras González, Manuel, "El Programa Enciclopédico de la Puerta del Cielo en el Panteón Real de San Isidoro de León," Compostellanum 45/3-4 (2000), 657-94.

Castiñeiras, Manuel, "Libro de Horas de Fernando I y Sancha," in Maravillas de la España Medieval. Tesoro sagrado y monarquía, ed. Isidro Bango (Madrid, 20o1), pp. $232-34$.

Castiñeiras, Manuel, "Libro de Horas," in Enciclopedia del Románico en Galicia 2, eds. José María Pérez González, and José Carlos Valle Pérez (Aguilar de Campoo, 2013), pp. 1143-49.

Claussen, Peter Cornelius, Die Kirchen der Stadt Rom in Mittelalter 1050-1300, A-F (Stuttgart, 2002). 
Colección documental del archivo de la catedral de León (1032-1109) 4, ed. José Manuel Ruiz Asencio (León, 199o).

Cosmen, Concepción, and Moráis Morán, José Alberto, "Renovación e internacionalización en la escultura románica del reino de León a mediados del siglo XII: Santa María de Carracedo," in Vestir la arquitectura: XXII CEHA 1, ed. René Payo (Burgos, 2019), pp. 34-39.

Debiais, Vincent, "Mostrar, significar, desvelar. El acto de representar según las inscripciones medievales," Codex Aquilarensis 29 (2013), 169-186.

de Blaauw, Sible, "A mediaeval portico at San Giovanni in Laterano: the Basilica and its ancient conventual building," Papers of the British School at Rome $5^{8}$ (1990), 299-316.

de Castro, César García, El Arca Santa de la catedral de Oviedo (Aguilar de Campoo, 2017). de Eguren, José María, Memoria descriptiva de los códices notables conservados en los archivos eclesiásticos de España (Madrid, 1859).

de Francisco Olmos, José María, "El nacimiento de la moneda en Castilla: de la moneda prestada a la moneda propia," in IJornadas Científica sobre Documentación jurídicoadministrativa, económico-financiera y judicial del reino castellano-leonés, siglos $X$ XIII (Madrid, 2002), pp. 303-46.

Delgado Valero, Clara, "El cetro como insignia de poder durante la Edad Media," in Los clasicismos en el arte español, Actas del X Congreso del CEHA (Madrid, 1994), pp. $45^{-5}$.

de Morales, Ambrosio, Viage a los reynos de Leon, y Galicia, y principado de Asturias (Madrid, 1765).

de Sandoval, Prudencio, Primera parte de las fundaciones de los Monasterios del Glorioso Padre San Benito (Madrid, 16o1).

de Sandoval, Prudencio, Catálogo de los obispos que ha tenido la santa iglesia de Pamplona, desde el año de ochenta que fue el primero della el santo martyr Fermín, su natural ciudadano (Pamplona, 1614).

de Silva y Verástegui, Soledad, "Los primeros retratos reales en la miniatura hispánica altomedieval. Los monarcas de Pamplona y de Viguera," Príncipe de Viana 160-161 (1980), 257-61.

de Silva y Verástegui, Soledad, Iconografía del siglo X en el Reino de Pamplona-Nájera (Pamplona, 1984).

de Silva y Verástegui, Soledad, "La miniatura en el Reino de Pamplona-Nájera (9051076)," in García Sánchez III 'el de Nájera' un reyy un reino en la Europa del siglo XI, ed. José Ignacio de la Iglesia Duarte (Nájera, 2005), pp. 327-65.

de Silva y Verástegui, Soledad, "Imágenes matrimoniales en la Alta Edad Media en España: la pareja real," Príncipe de Viana 77/265 (2016), 581-61o.

Díaz y Díaz, Manuel C., "Vigilán y Sarracino: sobre composiciones figurativas en la Rioja del siglo X," in Lateinische Dichtungen des X. und XI. Jahrhunderts: Festgabe 
für Walther Bulst zum 8o. Geburtstag, eds. Walter Berschin, and Reinhard Düchting (Heidelberg, 1981), pp. 6o-92.

Díaz y Díaz, Manuel C., Códices visigóticos en la monarquía leonesa (León, 1983).

Eberlein, Johann Konrad, Apparitio regis - revelatio veritatis: Studien zur Darstellung des Vorhangs in der bildenden Kunstvon der Spätantike bis zum Ende des Mittelalters (Wiesbaden, 1982).

En el principio: Génesis de la Catedral Románica de Santiago de Compostela. Contexto, construcción y programa iconográfico, ed. José Luis Senra (Santiago de Compostela, 2014).

Estella Marcos, Margarita M., La escultura del marfil en España: románica y gótica (Madrid, 1984, repr. Valladolid, 2012).

Estepa Díez, Carlos, Alfonso VIy su legado: actas del congreso internacional (León, 2012). Fernández González, Etelvina, "Relicario de San Isidoro," in Sancho el Mayor y sus herederos. El linaje que europeizó los reinos hispanos (Pamplona, 2006), pp. 136-41.

Fernández González, Etelvina, "La imago regis y de la jerarquía eclesiástica a través de las artes plásticas (siglos IX-XII)," in Monarquía y sociedad en el Reino de León. De Alfonso III a Alfonso VII 2 (León 2007), pp. 45-96.

Fernández González, Etelvina, "Imagen, devoción y suntuosidad en las aportaciones de Fernando I y Sancha al tesoro de San Isidoro de León," in Monasterios y monarcas. Fundación, presencia y memoria regia en monasterios hispanos medievales, ed. José Angel García de Cortázar (Aguilar de Campoo, 2012), pp. 16o-97.

Férotin, Marius, "Deux manuscrits wisigothiques de la Bibliothèque de Ferdinand Ier," Bibliothèque de l'École des Chartes 62 (1901), 374-87.

Férotin, Marius, Le Liber Ordinum en usage dans l'église Wisigothique et Mozarabe d'Espagne du cinquième au onzième siècle (Paris, 1904).

Fita, Fidel, “Santa María la Real de Nájera. Estudio crítico," Boletín de la Real Academia de la Historia 26/3 (1895), 155-98.

Franco Mata, Ángela, "El tesoro de San Isidoro y la monarquía leonesa," Boletín del Museo Arqueológico Nacional 9 (1991), pp. 35-67.

Franco Mata, Ángela, “Liturgia hispánica y marfiles talleres de León y San Millán de la Cogolla en el siglo XI," Codex Aquilarensis 22 (2006), 92-145.

Gallego García, Raquel, La eboraria durante el reinado de Fernando I. La perspectiva de unas artes suntuarias europeas, Ph.D. (Univ. Complutense de Madrid, 2010).

Galván Freile, Fernando, "Documento de la fundación del monasterio de Santa María de Nájera," in Sancho el Mayor y sus herederos. El linaje que europeizó los reinos hispanos (Pamplona, 2006), pp. 287-9o.

Galván Freile, Fernando, 'El 'Liber Canticorum et Horarum' de Sancha (B.G.U.S., MS 2668): entre la tradición prerrománica y la modernidad," in Hispaniens Norden im 11. Jahrhundert, Christliche Kunst im Umbruch, eds. Achim Arbeiter, Christine Kothe, and Bettina Marten (Petersberg, 2009), pp. 248-56 (repr. in Imágenes del poder en la 
Edad Media. Selección de Estudios del Prof. Dr. Fernando Galván Freile, 1 (León, 2011), pp. 451-67).

Gambra Gutiérrez, Andrés, Alfonso VI: Cancillería, Curia e Imperio (León, 1997).

Garipzanov, Ildar H., The Symbolic Language of Authority in the Carolingian World (c. 751-877) (Leiden, 2008).

Gómez-Moreno, Manuel, "El Arca de las reliquias de San Isidoro," Archivo Español de Arte y Arqueología 8/24 (1932), 205-12.

Gómez-Moreno, Manuel, "El arca de las reliquias de San Isidoro de León," Archivo Español de Arte 48 (1940), 205-12.

Gómez-Moreno, Manuel, and Vázquez Parga, Luis, En torno al crucifijo de los reyes Fernando y Sancha (Madrid, 1965).

Halbwachs, Maurice, La mémoire collective (Paris, 1950).

Halbwachs, Maurice, La Topographie légendaire des Évangiles en Terre sainte. Étude de mémoire collective (Paris, 1941; repr. and eds. Marie Jaisson, Danièle Hervieu-Léger, Jean-Pierre Cléro, Sarah Gensburger, and Éric Brian, Paris, 2008).

Harris, Julie Ann, “Culto y narrativa en los marfiles de San Millán de la Cogolla," Boletín del Museo Arqueológico Nacional 9/1-2 (1991), 69-85.

Henriet, Patrick, "Rois en prière et oracle sibyllin. Une relecture de certaines scènes du reliquaire de San Millán de la Cogolla (années 1060-1070)," Cultura y poder en la Edad Media peninsular. Studia historica. Historia medieval 33 (2015), pp. 51-67.

Hernández-Canut Fernández-España, León, "El primer retrato regio en la moneda castellana," in XIII Congreso Internacional de Numismática 2, eds. Carmen Alfaro Asins, Carmen Marcos Alonso, and Paloma Otero Morán (Madrid, 2005), pp. 1199-205.

Historia Silense, ed. Francisco Santos Coco (Madrid, 1921).

Historia silense, eds. Justo Pérez de Urbel, and Atilano González Ruiz-Zorrilla (Madrid, 1959).

Iñiguez, Francisco, Arte Medieval Navarro 2: Arte Románico (Pamplona, 1973).

Jasperse, Jitske, "Manly Minds in Female Bodies: Three Women and their Power through Coins and Seals," Arenal: Revista de historia de mujeres 25/2 (2018), 296-321.

Keller,Hagen, “DasneueBilddesHerrschers.ZumWandelder'Herrschaftsrepräsentation' unter Otto dem Großen," in Ottonische Neuanfänge. Symposion zur Ausstellung 'Otto der Große, Magdeburg undEuropa,'eds. Bernd Schneidmüller, and Stefan Weinfurter (Mainz, 2001), pp. 189-211.

Klinka, Emmanuelle, "Ego misera et peccatrix ...: El Liber mozarabicus canticorum et horarum (Salamanca, MS 2668)," e-Spania 13 (2012). Accessed 2019 June 6.

Krynitz, Ulrich, "Bilder aus dem Goslarer Evangeliar Codex Caesareus," in Codex Caesareus: das Goslarer Evangeliar Kaiser Heinrichs III., die 'Kaiserbibel' aus Uppsala (Benediktinerabtei Kloster Echternach um 1050): zum 1000. Geburtstag Kaiser Heinrichs III. in der Kaiserpfalz/Goslar (03.09.2017-28.02.2018: Leihgabe der 
Universitätsbibliothek Carolina Rediviva Uppsala/Schweden), ed. Ulrich Krynitz (Goslar, 2017), pp. 30-69.

Lasko, Peter, Ars Sacra, 800-1200 (Harmondsworth, 1972, repr. Madrid, 1999).

Le Morvan, Gaël, "Reinos e imperio: la Historia legionensis (llamada silensis) y la reivindicación leonesa de la herencia visigótica," e-Spania 14 (2012). Accessed 2019 Oct 1.

Liber Ordinum Episcopal (cod. Silos, Arch. Monástico, 4), ed. José Janini (Silos, 1991).

Linage Conde, Antonio, Alfonso VI, el rey hispano y europeo de las tres religiones: $1065-$ 1109 (Gijón, 2006).

López Serrano, Matilde, El Códice Aureo. Los cuatro Evangelios. Siglo XI (Madrid, 1987). López Alsina, Fernando, "La Concordia de Antealtares," in Santiago, Camino de Europa, Culto y Cultura en la Peregrinación a Santiago de Compostela (Santiago de Compostela, 1993).

Manzano, José, Viday portentosos milagros del glorioso San Isidoro, Arzobispo de Sevilla y egregio Doctory maestro de las Españas (Salamanca, 1732).

Martin, Georges, "La Historia legionensis (llamada silensis) como memoria identitaria de un reino y como autobiografía," e-Spania 14 (2012). Accessed 2019 Aug 11.

Martin, Georges, “Ordoño Sisnández, autor de la Historia legionensis (llamada silensis). Notas histórico-filológicas sobre un ego fundador," e-Spania 14 (2012) Accessed 2019 Oct 12.

Martin, Therese, "De 'gran prudencia, graciosa habla y elocuencia' a 'mujer de poco juicio y ruin opinión': Recuperando la historia perdida de la reina Urraca," Compostellanum 50/1-4 (2005), 551-78.

Martin, Therese, Queen as King. Politics and Architectural Propaganda in Twelfth-century Spain (Leiden, 20o6).

Martin, Therese, "Mujeres, hermanas e hijas: el mecenazgo femenino en la familia de Alfonso VI," Anales de historia del arte 2: Alfonso VI y el arte de su época, eds. Javier Martínez de Aguirre, and Marta Poza (Madrid, 2011), 147-79.

Martin, Therese, "Caskets of Silver and Ivory from Diverse Parts of the World: Strategic Collecting for an Iberian Treasury," in The Medieval Iberian Treasury in the Context of Cultural Interchange, ed. Therese Martin, Medieval Encounters 25/1 (Leiden, 2019), pp. $1-38$.

Menéndez-Pidal de Navascués, Faustino, "La imagen del rey: signos y emblemas," in Sancho el Mayor y sus herederos. El linaje que europeizó los reinos hispanos (Pamplona, 2006), pp. 165-69.

Mínguez Fernández, José María, “Contexto social y político-militar del Reino de León al advenimiento de la dinastía navarra," in Alfonso VI y su época. I. Los precedentes del reinado (966-1065), eds. Etelvina Fernández González, and Javier Pérez Gil (León, 2007), pp. 17-35.

Montaner Frutos, Alberto, "Presencia y ausencia de Alfonso VI en la Historia Legionensis (hactenus Silensis nuncupata)," e-Spania 14 (2012) Accessed 2019 Oct 12. 
Montenegro, Julia, and del Castillo, Arcadio, "Los títulos de los reyes de León en los documentos medievales como reflejo de la continuidad del reino visigodo de Toledo," Estudios de Historia de España 13 (2011), 13-36.

Moráis Morán, José Alberto, "Pervivencias de la antigüedad clásica en la Edad Media hispana. El spolium in se: a propósito del cáliz de doña Urraca," in Perfiles de Grecia y Roma. Actas del XII Congreso Español de Estudios Clásicos (Madrid, 20o9), pp. 904-27.

Moráis Morán, José Alberto, La arqueta de San Adrián y el culto a sus reliquias en el antiguo reino astur leonés (Valparaíso, 2016).

Moráis Morán, José Alberto, "Reliquiae recondite. Invisibilidad y expansión visual de los despojos santos en la Alta Edad Media hispana," Historia 396, 8/2 (2018), 145-87.

Moráis Morán, José Alberto, and Cosmen Concepción "La desaparecida portada románica del monasterio de Santa María de Carracedo (León)," Anuario De Estudios Medievales 50/1 (2020), 231-266.

Moralejo Álvarez, Serafín, "Les Arts somptuaires hispaniques,aux environt du 110o," Les Cahiers de Saint-Michel de Cuxa 13 (1982), 285-310.

Moralejo Álvarez, Serafín, "Notas a la ilustración del Libro de Horas de Fernando I," in Libro de Horas de Fernando I de León. Edición facsímile do manuscrito 609 (Res. 1) da Biblioteca Universitaria de Santiago de Compostela, ed. Manuel C. Díaz y Díaz (Santiago de Compostela, 1995), pp. 53-63.

Mozo Monroy, Manuel, and García Montes, Francisco Javier, "Primeras labras de vellón acuñadas en Toledo (ss. XI-XII). Propuesta de interpretación iconográfica," Parva Urbs o (2009), 16-18.

Mozo Monroy, Manuel, and García Montes, Francisco Javier, "Aporte histórico y documental sobre el dinero de busto godo de Alfonso VI, rey de León y Castilla," Gaceta Numismática 180 (2011), 67-82.

Nodar Fernández, Victoriano, “Imágenes para el príncipe, imágenes para el monje. Función y decoración de la cabecera de la catedral de Santiago de Compostela (1075-1101)," Codex Aquilrensis 27 (2011), 39-54.

Park, Marlene, "The Crucifix of Fernando and Sancha and Its Relationship to North French Manuscripts," Journal of the Warburg and Courtauld Institutes 36 (1973), 77-91. Pérez Llamazares, Julio, El tesoro de la Real Colegiata de San Isidoro de León (reliquias, relicarios y joyas artisticas) (León, 1925).

Pérez Llamazares, Julio, Historia de la Real Colegiata de San Isidoro de León (León, 1927). Perrier, Daniele, "Die spanische Kleinkunst des 11. Jahrhunderts. Zur Klärung ihrer stilistischen Zusammenhänge im Hinblick auf die Frage ihrer Beziehungen zur Monumentalskulptur," Aachener Kunstblätter 52 (1984), pp. 29-150.

Prado-Vilar, Francisco, "Lacrimae rerum: San Isidoro de León y la memoria del padre," Goya 328 (2009), 195-221.

Redemptus, Relatio de transitu beatissimi Isidori episcopi, PL, 81, 30-32. 
Reglero de la Fuente, Carlos, "La renovación cluniacense del benedictinismo: San Isidro de Dueñas (1073-1228)," in Los grandes monasterios benedictinos hispanos de época románica: (1050-1200), eds. José Ángel García de Cortázar, and Ramón Teja (Aguilar de Campoo, 2007), pp. 59-86.

Reglero de la Fuente, Carlos, Cluny en España: los prioratos de la provincia y sus redes sociales (1073-c. 1270) (León, 2008).

Reglero de la Fuente, Carlos, "La Crónica najerense, Santa María de Nájera y Cluny," e-Spania 7 (2009). Accessed 2019 Nov 21.

Reglero de la Fuente, Carlos, "El Camino de Santiago, Cluny y la monarquía leonesa," in Desperta Ferro. Arqueología e Historia 6 (2016), 46-51.

Risco, Manuel, España Sagrada, t. 36: Memorias de la Santa Iglesia esenta de León (Madrid, 1787).

Risco, Manuel, Iglesia de León, y monasterios antiguos y modernos de la misma ciudad (Madrid, 1792).

Rodríguez Viejo, Jesús, "Imagen y devoción en el Diurnal de Fernando y Sancha," Románico 26 (2018), 8-15.

Roma Valdés, Antonio, Emisiones monetarias leonesas y castellanas de la Edad Media. Organización, economía, tipos y fuentes (Madrid, 2010).

Rubio, Juan Pablo, "Introducción del Rito Romano y reforma de la Iglesia Hispana en el siglo XI: de Sancho III el Mayor a Alfonso VI," in La reforma gregoriana en España, ed. Nicolás Álvarez (Madrid, 2011), pp. 55-76.

Sabourin, Paul, "Perspective sur la mémoire sociale de Maurice Halbwachs," Sociologie et sociétés 29/2 (1997), 139-61.

Sánchez Candeira, Alfonso, Castilla y León en el siglo XI, estudio del reinado de Fernando I, ed. Rosa Montero Tejada (Madrid, 1999).

Sánchez Cantón, Francisco Javier, Los retratos de los reyes de España (Madrid, 1948).

Sansterre, Jean-Marie, and Henriet, Patrick, "De l'inanimis imago à l'omagem mui bella. Méfiance à l'égard des images et essor de leur culte dans l'Espagne médiévale (VIIeXIIIe siècle)," Edad Media. Revista de Historia 10 (2009), 37-92.

Serrano Coll, Marta, Effigies Regis Aragonum. La imagen figurativa del rey de Aragón en la Edad Media (Zaragoza, 2015).

Sicart, Angel, Pintura medieval: la miniatura (Santiago de Compostela, 1981).

Sirantoine, Hélène, Imperator Hispaniae. Les idéologies impériales dans le royaume de León (IXe-XIIe siècles) (Madrid, 2012).

Villanueva Fernández, Ana, "La indumentaria regia en el Reino de León en el siglo XI: el libro de horas de Fernando I y Doña Sancha," in Imágenes del poder en la Edad Media. Estudios 'in memoriam' del Prof. Dr. Fernando Galván Freile 2 (León, 2011), pp. 485-500.

Vorderstemann, Jürgen, "Heinrichs III. Goldenes Evangeliar für den Speyerer Dom als Ausdruck des theokratischen Reichsgedankens," in Ausstellungen zum Domjubiläum (Speyer, 1980), pp. 97-103. 
Walker, Rose, "The Wall Paintings in the Panteon de los Reyes at Leon: A Cycle of Intercession," The Art Bulletin 82/2 (2000), 200-25.

Walker, Rose, "Becoming Alfonso VI: the king, his sister and the 'arca santa' reliquary," Anales de historia del arte 2: Alfonso VIy el arte de su época, eds. Javier Martínez de Aguirre, and Marta Poza (Madrid, 2011), 391-412.

Weinfurter, Stefan, The Salian Century: Main Currents in an Age of Transition. The Middle Ages (Philadelphia, 1999).

Werckmeister, Otto K., "The First Romanesque Beatus Manuscripts and the Liturgy of the Death," in Actas del Simposio para el estudio de los Codices del 'Comentario al Apocalipsis' de Beato de Liebana 2 (Madrid, 1980), pp. 165-200.

Werckmeister, Otto K., "The Art of the Frontier: Mozarabic Monasticism," in The Art of Medieval Spain, a.d. 50o-120o (New York, 1993), pp. 121-32.

Williams, John W., "Liber Testamentorum," in The Art of Medieval Spain, a.d. 500-1200 (New York, 1993), p. 247.

Williams, John W., "Prayer Book of Ferdinand and Sancha," in The Art of Medieval Spain, a.d. 500-1200 (New York, 1993), pp. 290-91.

Williams, John W., and Walker, Daniel, "Reliquary of Saint Isidore," in The Art of Medieval Spain, a.d. 500-1200 (New York, 1993), pp. 239-44.

Williams, John W., The Illustrated Beatus. A corpus of the illustrations of the commentary on the Apocalypse. II. The Ninth and Tenth Centuries (London, 1994).

Williams, John W., "León: The Iconography of a Capital," in Cultures of Power. Lordship, Status, and Process in Twelfth-Century Europe, ed. Thomas N. Bisson (Philadelphia, 1995), pp. 231-58.

Williams, John W., "Fernando I and Alfonso VI as Patrons of the Arts," Anales de historia del arte 2: Alfonso VIy el arte de su época, eds. Javier Martínez de Aguirre, and Marta Poza (Madrid, 2011), 413-35.

Yarza Luaces, Joaquin, Historia del Arte Hispánico 2, La Edad Media (Madrid, 1980).

Yarza Luaces, Joaquín, "La peregrinación a Santiago y la pintura y miniatura románicas," Compostelanum 30 (1985), 369-93.

Yarza Luaces, Joaquín, "Iconografía de la Crucifixión en la miniatura española: siglos X al XII," Archivo Español de Arte 47-185 (1974), 13-38.

Yarza Luaces, Joaquín, "Las miniaturas del Liber Testamentorum," in Liber Testamentorum Ecclesiae Ovetensis (Barcelona, 1995), pp. 147-230. 


\section{Illustrations}

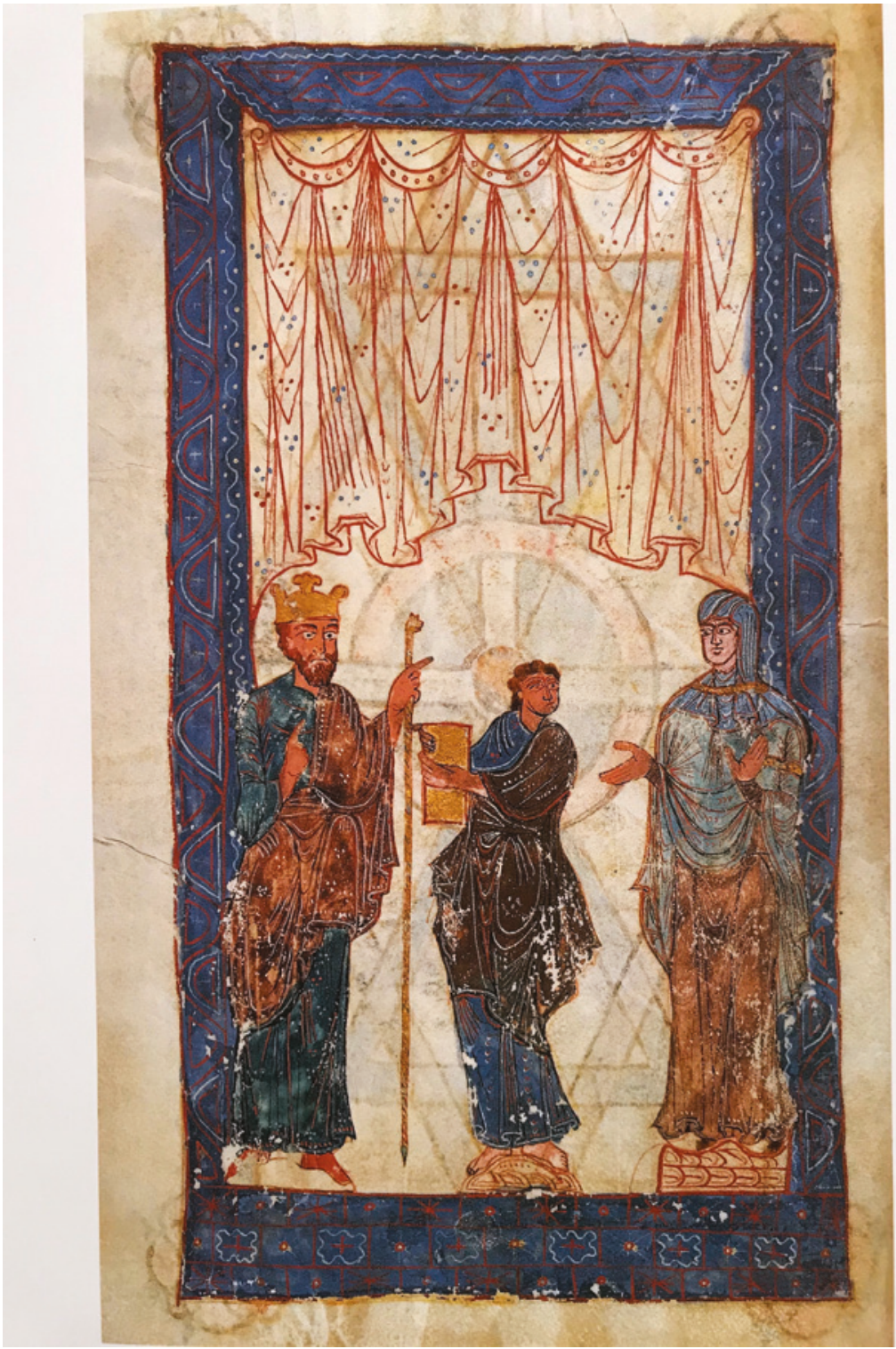

FIGURE 11.1 Book of Daily Hours (Diurnal) of Fernando I and Sancha (1055). Santiago de Compostela, Biblioteca Xeral da Universidade, ms. Res. 1, f. 6v (now 3v): court scene, introduction of the book to King Fernando I WITH PERMISSION, (C) USC 


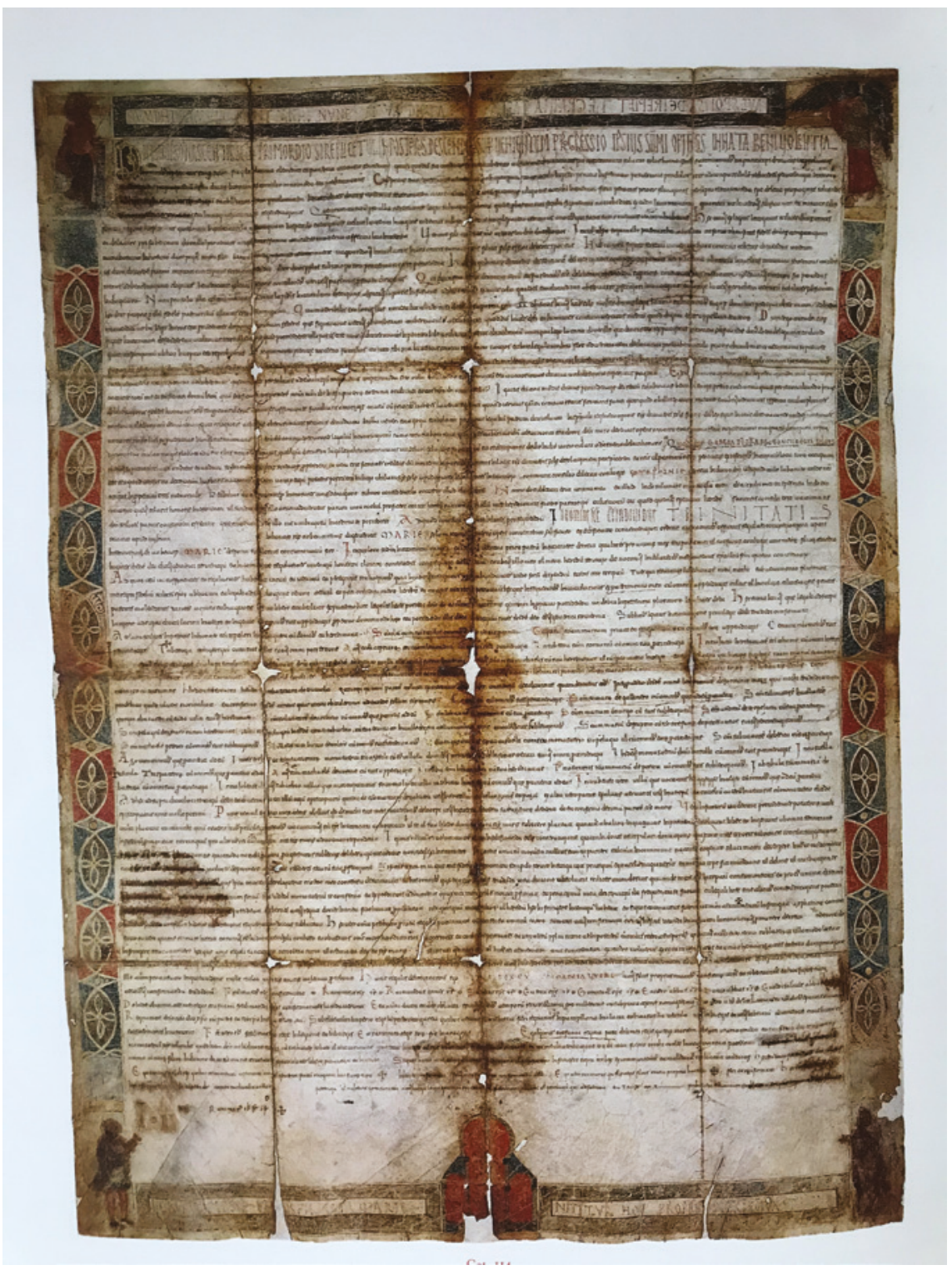

FIGURE 11.2 Foundational diploma of the monastery of Santa María la Real de Nájera (1054). Madrid, Real Academia de la Historia, sig. 290

WITH PERMISSION, (C) RAH 


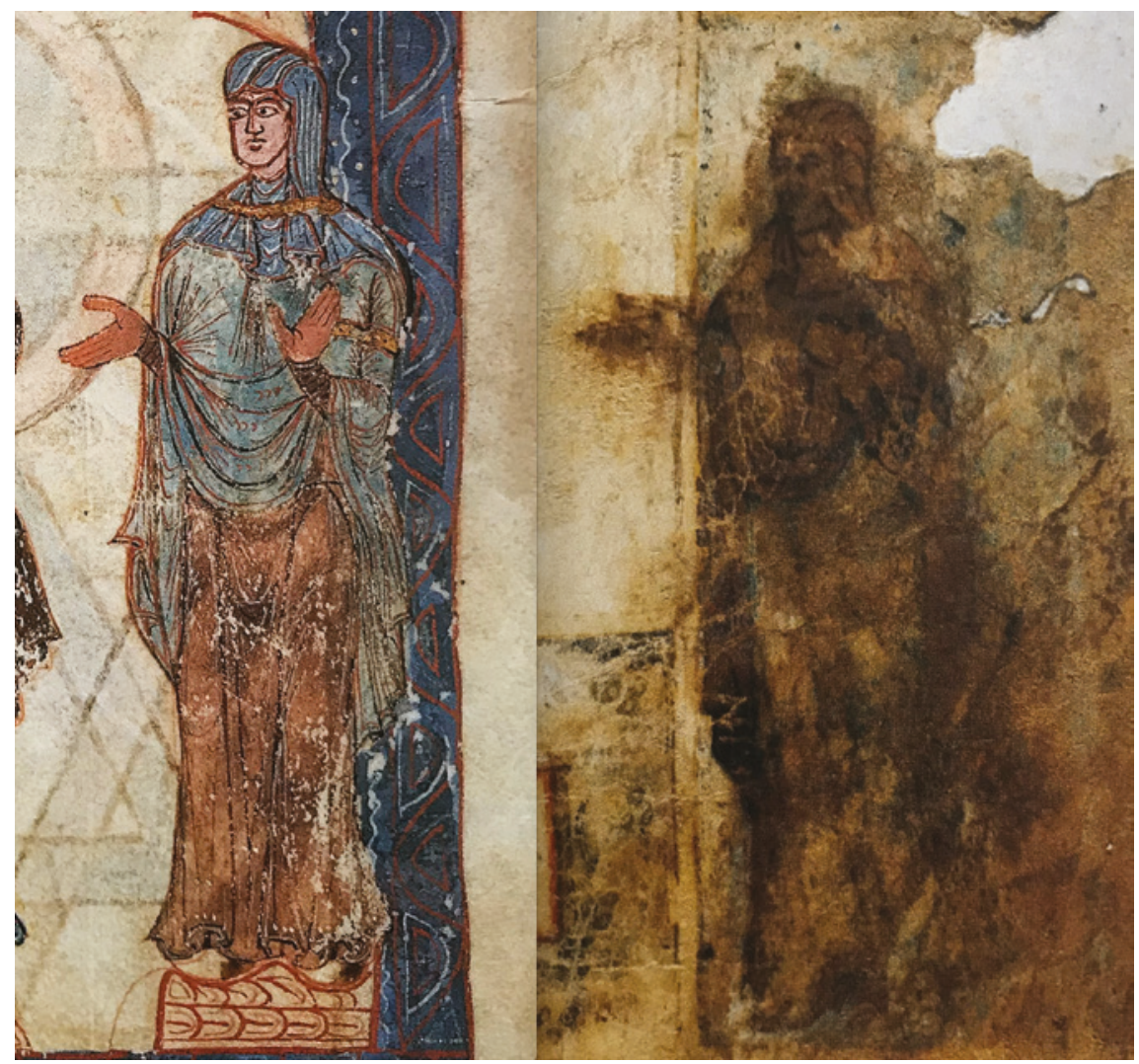

FIGURE 11.3 Detail of Foundational diploma of the monastery of Santa María la Real de Nájera; court scene from the Book of Daily Hours of Fernando I and Sancha 


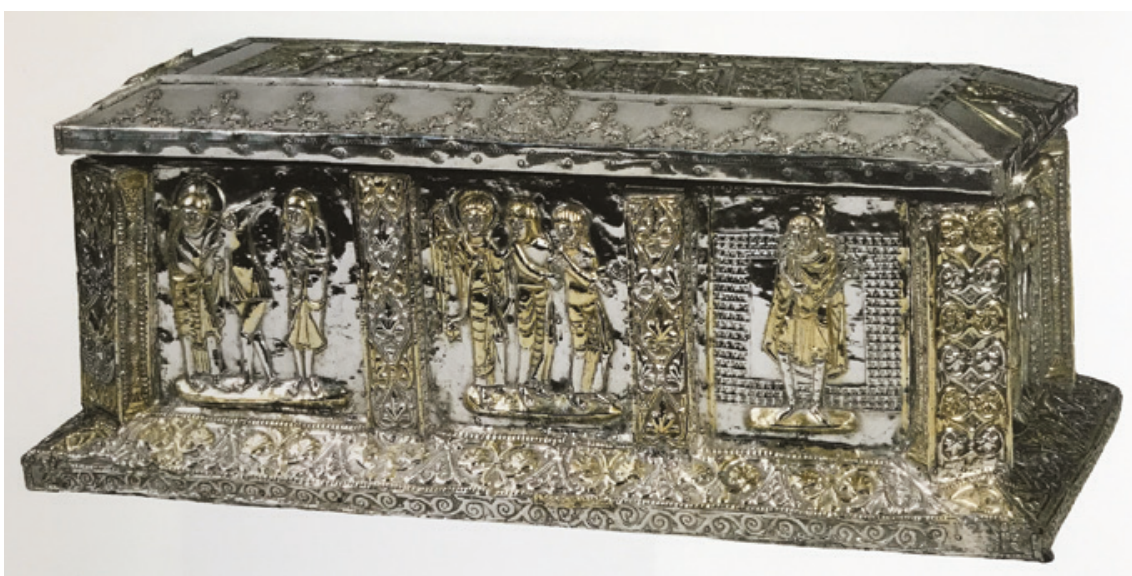

FIGURE 11.4 Reliquary of Saint Isidore (1063). León, San Isidoro, Tesoro de la colegiata AUTHORIZED BY THE MUSEUM-ARCHIVE

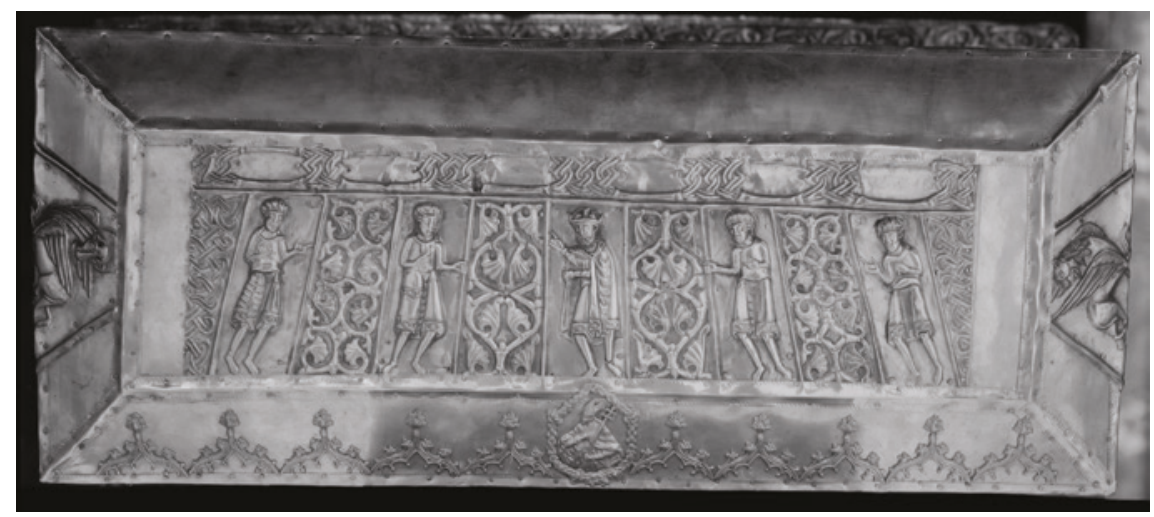

FIGURE 11.5 Reliquary of Saint Isidore, cover: King Fernando I surrounded by four members of his court (1063). León, San Isidoro, Tesoro de la colegiata AUTHORIZED BY THE MUSEUM-ARCHIVE 

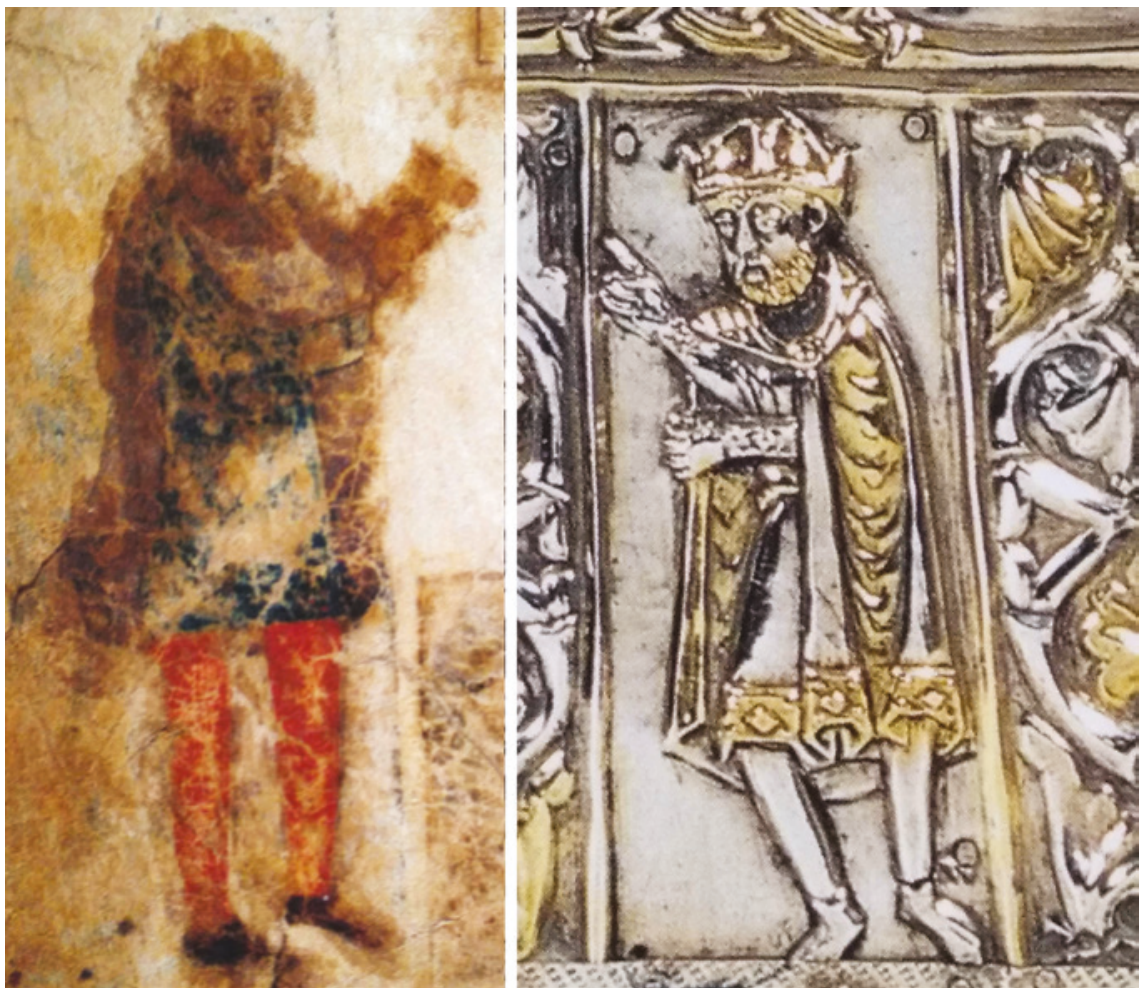

FIGURE 11.6 Detail of Foundational diploma of the monastery of Santa María la Real de Nájera: García III (1054). Madrid, Real Academia de la Historia, sig. 29o; Reliquary of Saint Isidore, cover: King Fernando I (1063). León, San Isidoro, Tesoro de la colegiata

AUTHORIZED BY THE MUSEUM-ARCHIVE 


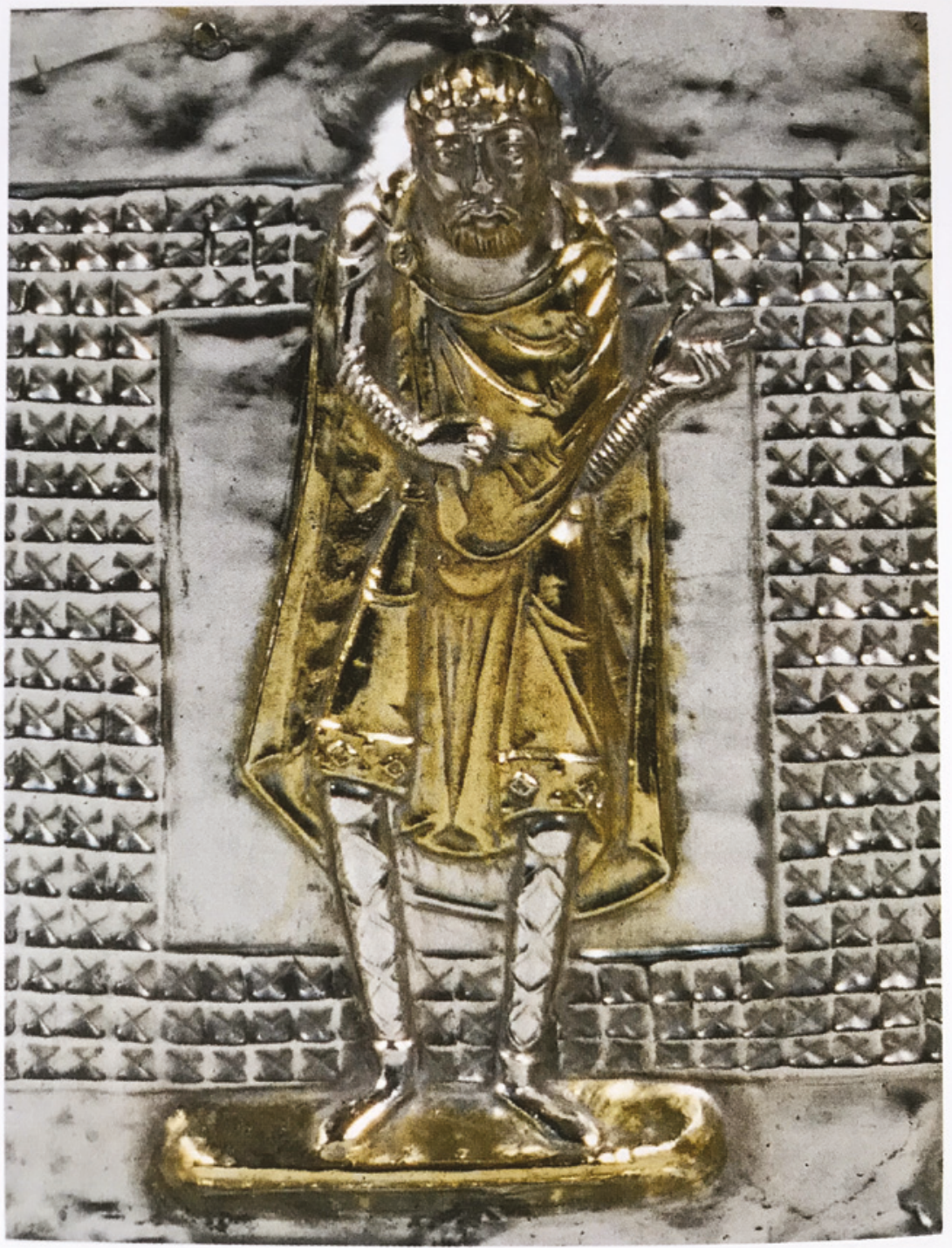

FIGURE 11.7 Reliquary of Saint Isidore, front: Fernando I without royal emblems (1063). León, San Isidoro, Tesoro de la colegiata

AUTHORIZED BY THE MUSEUM-ARCHIVE 


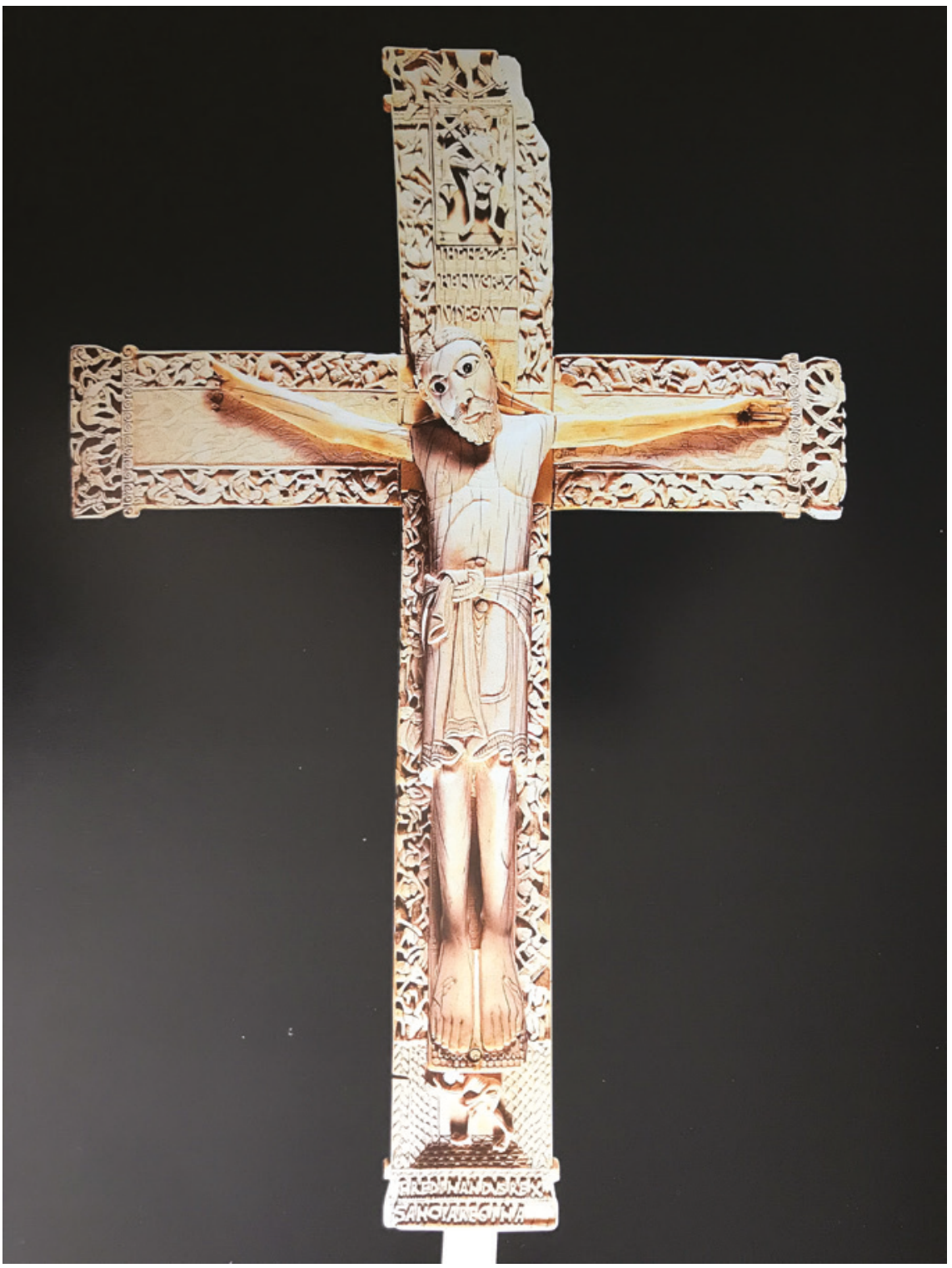

FIGURE 11.8 Ivory Cross of Fernando I and Sancha (ca. 1063). Madrid. Museo Arqueológico Nacional ( $\mathrm{n}^{\mathrm{O}}$ inv. 52.340)

AUTHORIZED BY THE MUSEUM 


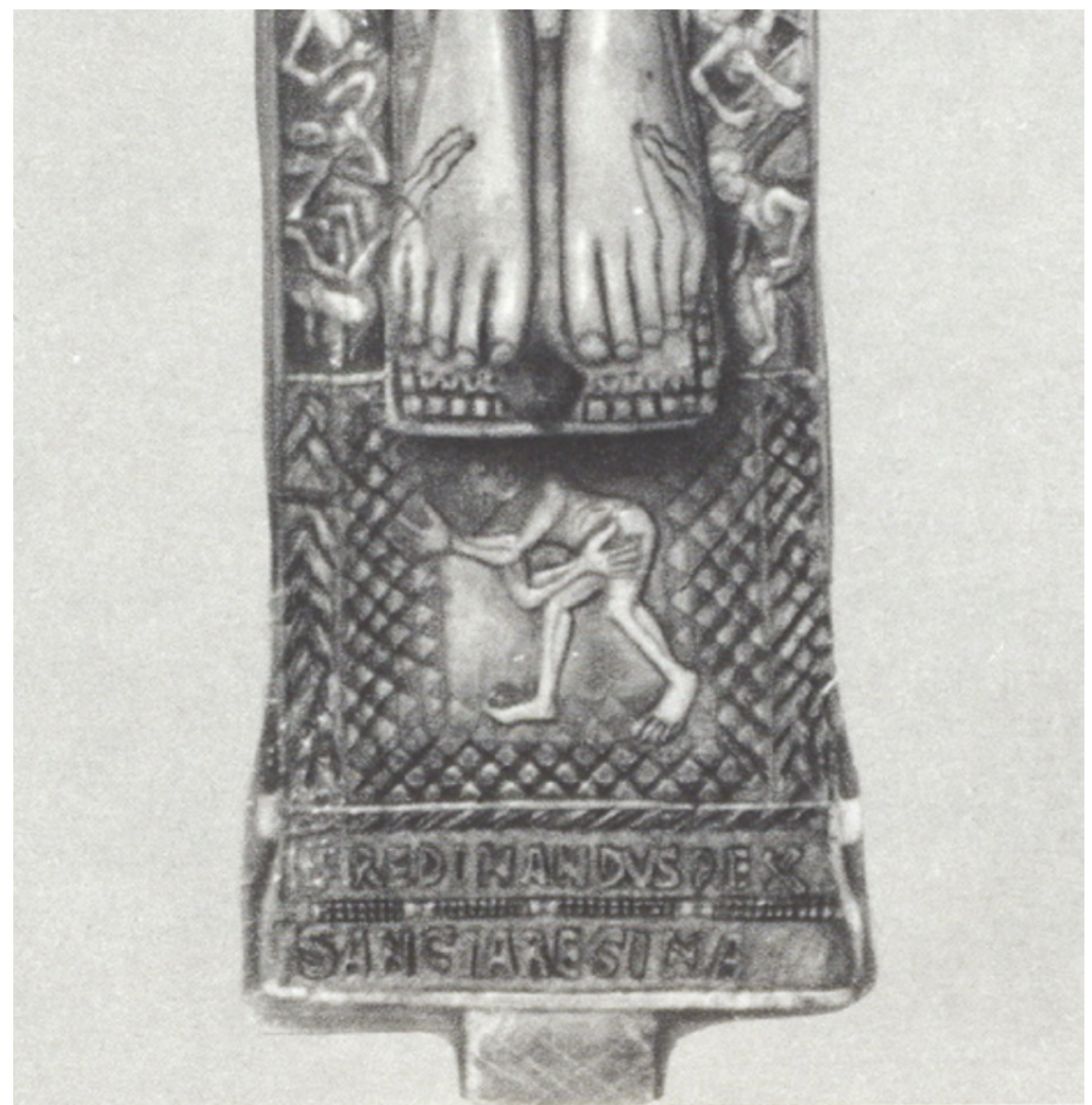

FIGURE 11.9 Ivory Cross of Fernando I and Sancha (ca. 1063). Madrid. Museo Arqueológico Nacional ( $n^{\circ}$ inv. 52.340). Detail of the bottom AUTHORIZED BY THE MUSEUM 


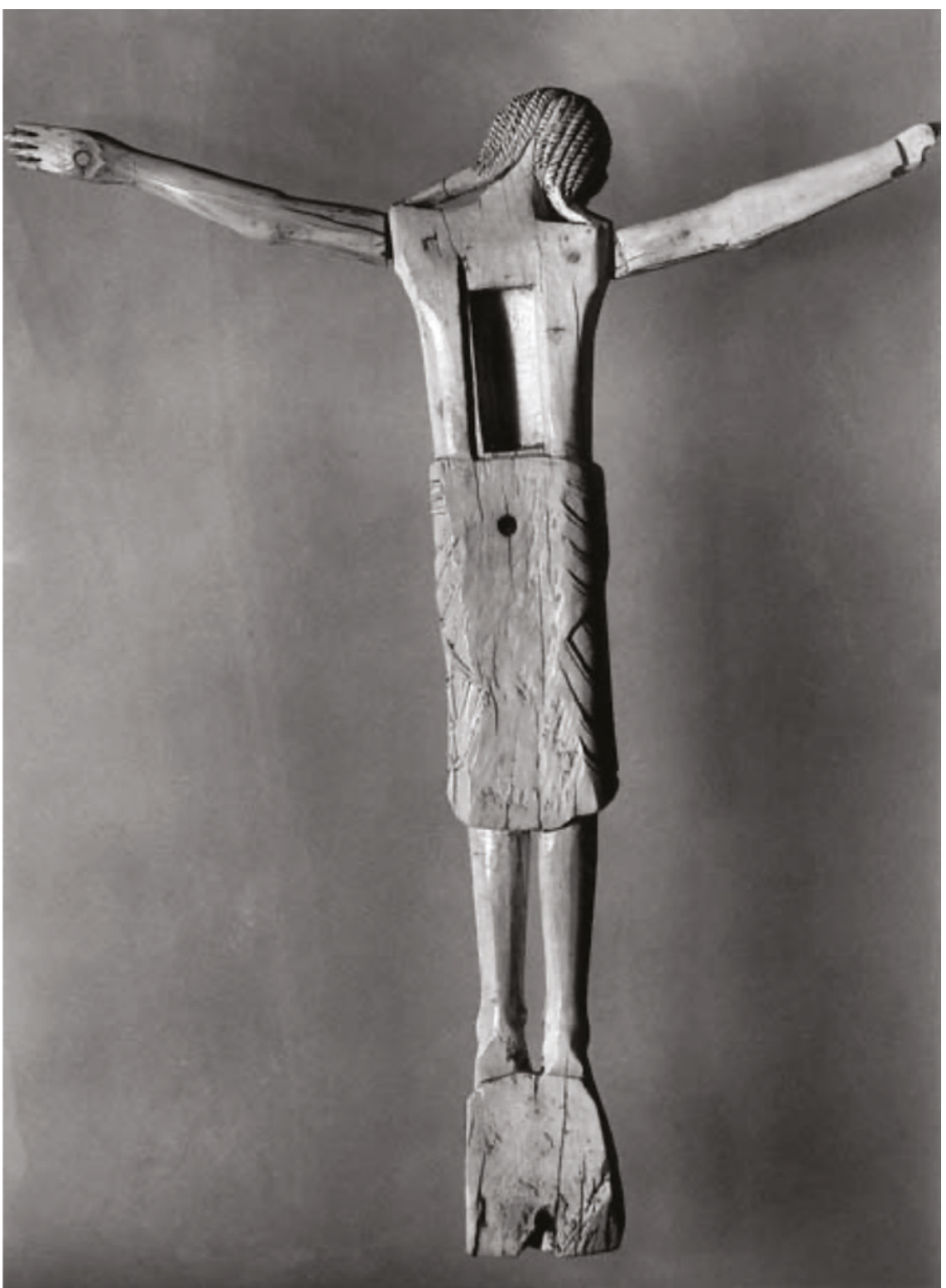

FIGURE 11.10 Ivory Cross of Fernando I and Sancha (ca. 1063). Madrid. Museo Arqueológico Nacional ( $\mathrm{n}^{\circ}$ inv. $5^{2 \cdot 340}$ ). Rear view of the figure of Christ, with the hole for the relic

AUTHORIZED BY THE MUSEUM 


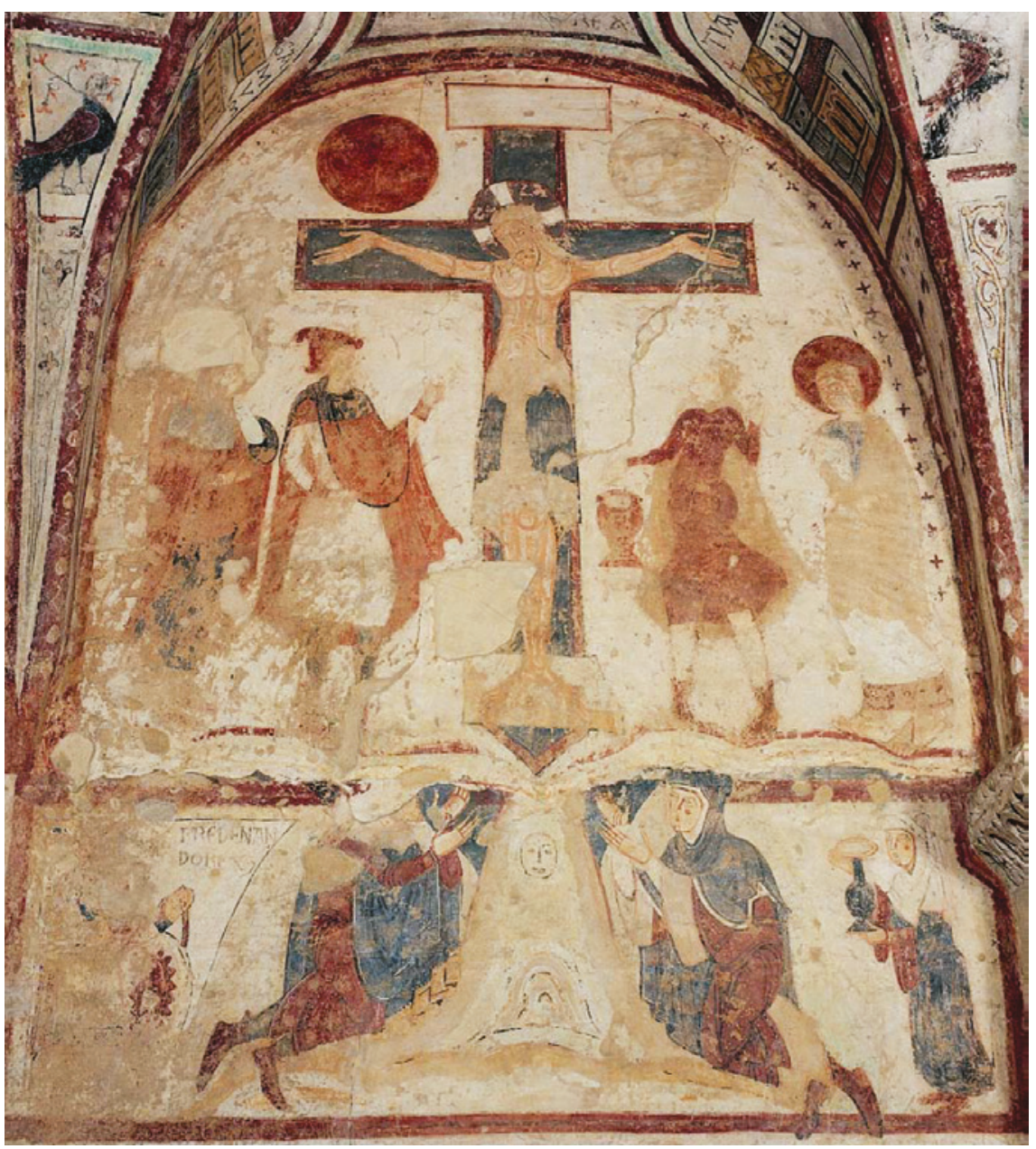

FIGURE 11.11 Mural Painting of "Pantheon of the Kings" (ca. 1090): Cross of Golgotha with the effigies of Fernando I and Sancha kneeling. León, San Isidoro AUTHORIZED BY THE MUSEUM-ARCHIVE 


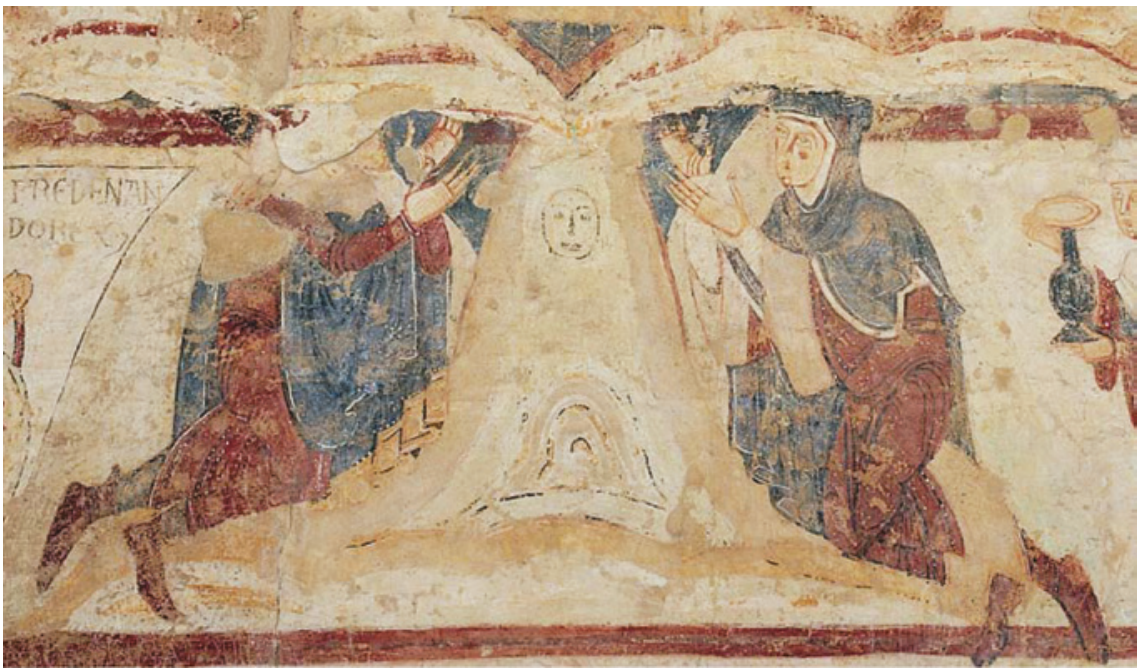

FIGURE 11.12 Mural Painting of "Pantheon of the Kings" (ca. 109o): Cross of Golgotha with the effigies of Fernando I and Sancha kneeling. León, San Isidoro. Detail AUTHORIZED BY THE MUSEUM-ARCHIVE

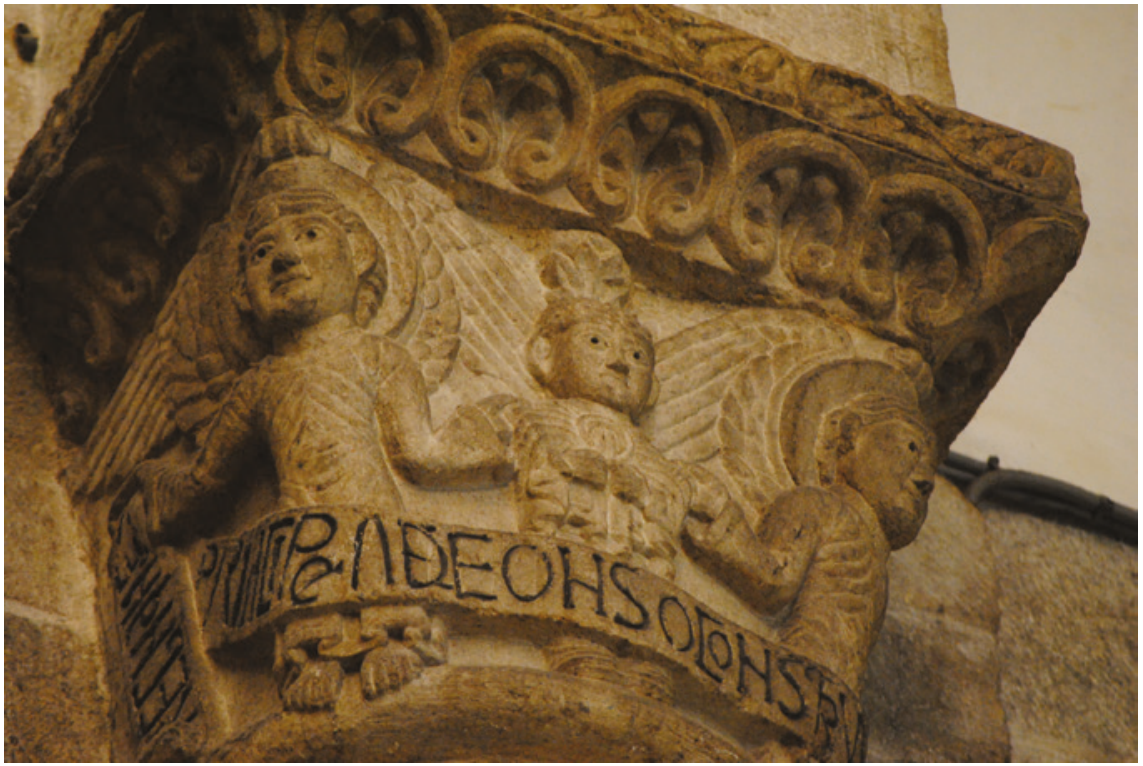

FIGURE 11.13 Ambulatory of the Cathedral of Santiago de Compostela (ca. 10751080): Capital with image of Alfonso vi flanked by two angels AUTHORIZED BY THE MUSEUM CATHEDRAL 


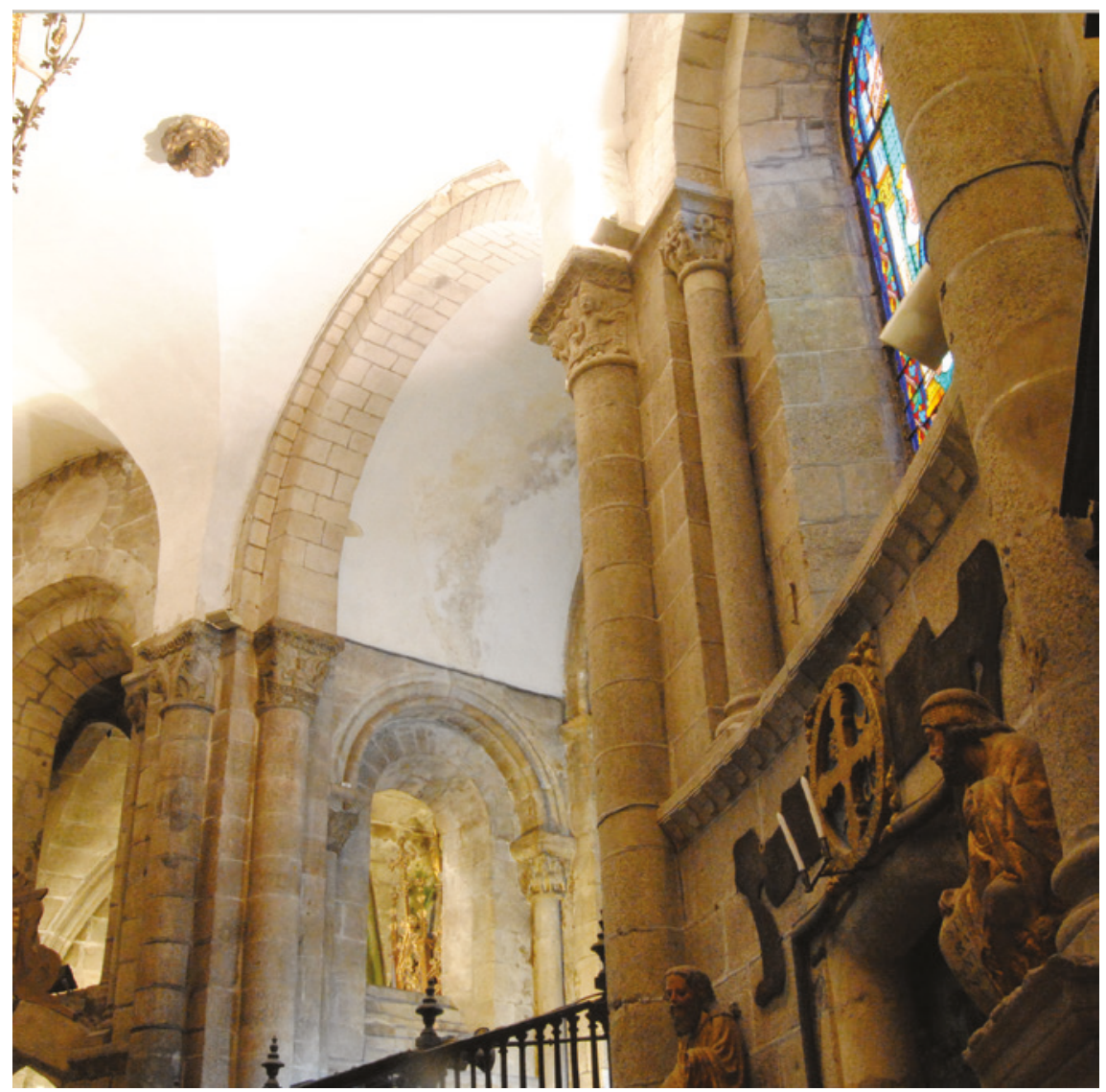

FIGURE 11.14 Ambulatory of the Cathedral of Santiago de Compostela (ca. 1075-1080): Two capitals with images of Alfonso vi and Bishop Peláez, in their architectural position AUTHORIZED BY THE MUSEUM CATHEDRAL 

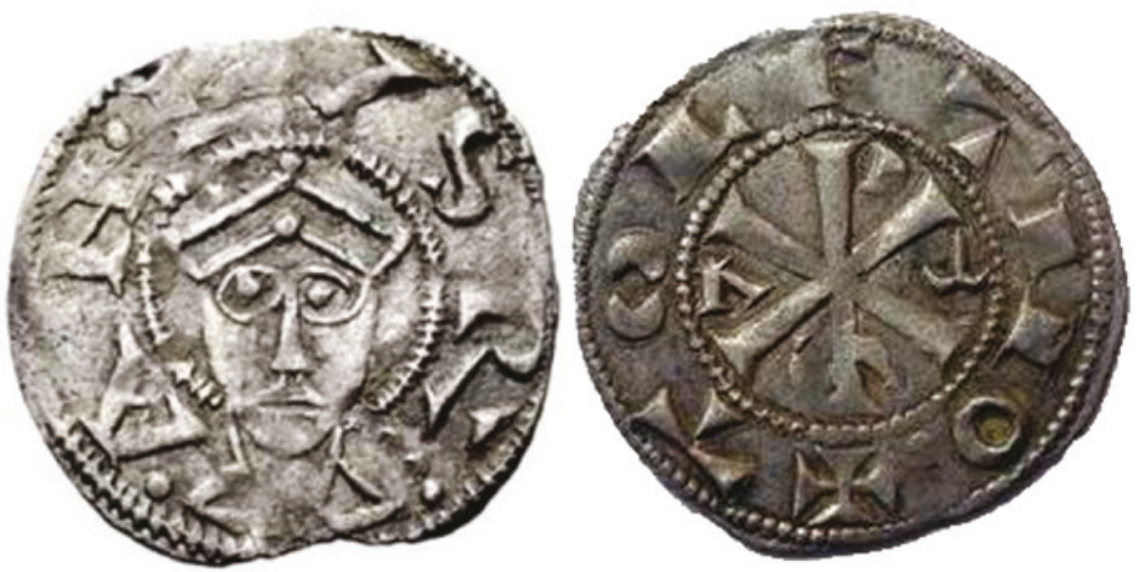

FIGURE 11.15 A dinero issued by Alfonso VI, ca. 1088

DAVID MARTÍNEZ CHICO, "LAS PRIMERAS ACUÑACIONES CRISTIANAS EN LA PENÍNSULA IBÉRICA", NUMISMÁTICO DIGITAL, 2014 HTTPS://WWW .NUMISMATICODIGITAL.COM/NOTICIA/6027/ARTICULOS-NUMISMATICA/ LAS-PRIMERAS-ACUNACIONES-CRISTIANAS-EN-LA-PENINSULA-IBERICA .HTML (ACCESSED 2020 AUGUST 06) 